\title{
GEOTHERMAL GRADIENT AND HEAT FLOW IN THE STATE OF RIO DE JANEIRO
}

\author{
Antonio Jorge de Lima Gomes ${ }^{1}$ and Valiya Mannathal Hamza ${ }^{2}$ \\ Recebido em 31 marco, 2005 / Aceito em 12 dezembro, 2005 \\ Received on March 31, 2005 / Accepted on December 12, 2005
}

\begin{abstract}
Results of geothermal studies carried out at 72 localities have been used in evaluation of temperature gradient and heat flow values of the upper crust in the state of Rio de Janeiro. The investigations included temperature logs in boreholes and wells, calculation of geothermal gradients, measurements of thermal conductivity and determination of heat flow density. In addition, estimates of temperature gradients and heat flow were also made for areas of thermo-mineral springs, based on the so-called geochemical methods. Analysis of these data sets, after incorporation of appropriate corrections (for the perturbing effects of drilling operations, topography and climate changes) has allowed for the first time a better understanding of the regional distribution of thermal gradients and heat flow within the study area. The results obtained indicate that geothermal gradient values are in the ranges of 14 to $26^{\circ} \mathrm{C} / \mathrm{km}$ in Precambrian metamorphic terrain and 19 to $33^{\circ} \mathrm{C} / \mathrm{km}$ in areas of Phanerozoic sedimentary basins. Most of the rock formations are characterized by thermal conductivity values varying from 2.2 to $3.6 \mathrm{Wm}^{-1} \mathrm{~K}^{-1}$. Consequently regionally averaged mean heat flow values are found to fall in the interval of 40 to $70 \mathrm{~mW} / \mathrm{m}^{2}$. Computer generated contour maps reveal that geothermal gradients and heat flow are systematically high in the western compared to the eastern parts of the state of Rio de Janeiro. There are indications that this geothermal anomaly is probably associated with the belt of Tertiary alkaline intrusives, between Itatiaia and Cabo Frio. Residual heat of large scale magma intrusions in the later part of the Tertiary period may be one of the possible mechanisms responsible for this thermal anomaly.
\end{abstract}

Keywords: Geothermal Gradient, Heat Flow, Rio de Janeiro.

RESUMO. Resultados de estudos geotérmicos efetuados em 72 localidades foram utilizados na avaliação de gradientes de temperatura e o fluxo geotérmico da crosta superior no Estado do Rio de Janeiro. As investigações incluíram a realização de perfilagens térmicas em furos e poços, determinação dos gradientes térmicos, medições de condutividades térmicas e estimativas da densidade do fluxo geotérmico. Como complementos, também foram estimados gradientes e fluxo geotérmico das áreas de ocorrências de fontes termo-minerais, utilizando métodos geoquímicos. Análises desses dados após a incorporação das correções apropriadas (efeitos de perfuração, topografia e variações climáticas recentes) tornaram possível pela primeira vez um melhor entendimento da distribuição regional de gradientes térmicos e do fluxo de calor na área de estudo. Os resultados obtidos indicam que os gradientes térmicos variam entre 14 e $26^{\circ} \mathrm{C} / \mathrm{km}$ nas regiões metamórficas Pré-Cambrianas e de 19 a $33^{\circ} \mathrm{C} / \mathrm{km}$ nas áreas de bacias sedimentares Fanerozóicas. Muitas das formações rochosas apresentaram condutividade térmica compreendida entre 2,2 e 3,6 Wm ${ }^{-1} \mathrm{~K}^{-1}$. Conseqüentemente, os valores médios encontrados para o fluxo geotérmico regional situam-se no intervalo de 40 a $70 \mathrm{~mW} / \mathrm{m}^{2}$. Mapas de contorno, preparado a fim de examinar as variações regionais, revelam que o gradiente e o fluxo térmico são sistematicamente mais elevados na parte oeste da área de estudo, em comparação com aquelas encontradas na parte leste. Existem indicações de que a anomalia geotérmica na parte oeste está provavelmente associada com a faixa das intrusivas alcalinas Terciárias situadas entre a região de Itatiaia e Cabo Frio. 0 calor residual das intrusões magmático do período Terciário superior configura-se como um dos possíveis mecanismos responsáveis por esta anomalia térmica.

Palavras-chave: Gradiente Térmico, Fluxo Geotérmico, Rio de Janeiro.

\footnotetext{
1 Laboratório de Geotermia, Observatório Nacional - MCT, R. Gal. José Cristino, 77 - São Cristóvão, 20921-400 Rio de Janeiro, RJ, Brasil. Tel: 5521 3878-9154; Fax: 5521 2580-7081-E-mail: ajlgomes@on.br

${ }^{2}$ Coordenação de Geofísica, Observatório Nacional - MCT, R. Gal. José Cristino, 77 - São Cristóvão, 20921-400 Rio de Janeiro, RJ, Brasil. Tel: 5521 3878-9131; Fax: 5521 2580-7081-E-mail: hamza@on.br
} 


\section{INTRODUCTION}

We report in the present work results of experimental determinations of geothermal gradients and heat flow carried out during the period of 1998 to 2001, in the state of Rio de Janeiro and adjacent areas. The history of geothermal studies in this segment of southeastern Brazil is relatively recent. Systematic investigations began during the second half of the decade of 1990, soon after the installation of the Geothermal Laboratory at the National Observatory (Observatório Nacional - ON/MCT). Prior to this period the only heat flow values reported for the state of Rio de Janeiro were estimates based on geochemical methods by Hamza \& Eston (1981) and Hurter et al. (1983). Lack of direct experimental determination of geothermal gradients and heat flow has been a major obstacle in quantitative evaluation of regional thermal fields of the crust within the study area.

In the present context of geothermal studies, it is convenient to point out that the thermal effects of past geologic events and tectonic episodes of Precambrian eras, which has lead to formation of basement complexes (consisting metamorphic fold belts, granitic batholiths and migmatite sequences), are of little consequence to the present thermal field. This is also largely true of the vertical crustal movements of Paleozoic and Mesozoic times, which has lead to the formation of sedimentary basins in the eastern and western parts of the study area. The reason is that the time elapsed since the cessation of magmatic and metamorphic activities and extensional episodes is much larger than the thermal time constant of the lithosphere (Smith \& Shaw, 1975). On the other hand, the intrusive and magmatic activities of the Tertiary period are likely to have measurable thermal imprints in the present temperature field of the crust (Hamza et al., 2005a). Thus the main objective of the present work has been not only determination of the present distribution of geothermal gradients and heat flow but also identification of eventual thermal perturbations of relatively recent tectonomagmatic events within the study area.

\section{TECTONIC SETTING}

The study area is situated almost entirely within the so-called Ribeira metamorphic fold belt, to the south of the São Francisco craton. The last major tectonic process that affected the basement rocks have been identified as the Braziliano folding event, which occurred during the period of 500 to $900 \mathrm{~m} . y$. The tectonic features of this region reflect the nature of geological processes that contributed to the formation of the stable part of the South American continental crust. It also reveals marked imprints of the geodynamic processes that affected its eastern part, since Phane- rozoic times. According to earlier studies of Almeida (1967) the basement of the southeastern coastal area of Brazil consist predominantly of metamorphic complexes, the main ones being the Paraíba do Sul, Juiz de Fora, Serra dos Órgãos and Fluminense. Several geologically distinct terrains have been recognized in the study area. The main rock types are gneisses, granulites, quartzites and marble covering nearly $69 \%$ of the study area. A number of batholiths are also found within the basement complex, covering an area of about $11 \%$. Granites, granitoids and migmatite complexes are found to occur along elongated structural belts in the northeast - southwest direction and also as isolated bodies. The ages of basal units of metamorphic rocks vary from Archean to Proterozoic. As has been pointed out by Haralyi \& Hasui (1982) a number of structural lineaments and faults occur on regional scale (N30 - 60E).

Sedimentary basins of Phanerozoic age occur within the Fluminense lowlands in the southwest and in the Campos basin in northeast coastal belt. Basins of relatively small lateral extent (Resende and Volta Redonda) also occur in the western part of the state of Rio de Janeiro. According to Riccomini et al. (1983) there are indications of recent vertical movements in some isolated localities during Quaternary times. There is some amount of seismic activity at shallow depths in the coastal area and also along the offshore belt.

The geological features and tectonic characteristics of the state of Rio de Janeiro have been outlined and discussed in detail in the relevant literature (see for example Oliveira et al., 1977; Fonseca, 1998; among others). A simplified version of the geologic map of the study area is reproduced in Figure 1 adapted from CIDE (2002).

A remarkable feature of the study area, that has possible relevance to geothermal studies, is the occurrence of tectonomagmatic activities during Mesozoic and Cenozoic times. Plutonic and intrusive activities have been extensive during Tertiary along the coastal belt (from Barra de São João to Cabo Frio) and also in the inland areas to the west in the direction of Itatiaia. A number of alkaline intrusive bodies have been identified, the major ones being Itatiaia, Passa Quatro, Rio Bonito, Soarinho, Tanguá, Mendanha, Marapicú, Itaúna, Cabo Frio, Morro Redondo, Tinguá, Serras dos Tomazes, Canaã and Morro de São João. Most of the intrusive activities are found to occur along an approximate eastwest belt between Itatiaia and Cabo Frio (Freitas, 1944; Almeida, 1967, 1977 and 1991; and Almeida et al., 1975). Herz (1977) and Hamza (1997) suggested that such alignments could be indicative of a hot spot track. According to Klein \& Vieira (1980) volcanic activity was significant during the period of 52 to 73 m.y., in 


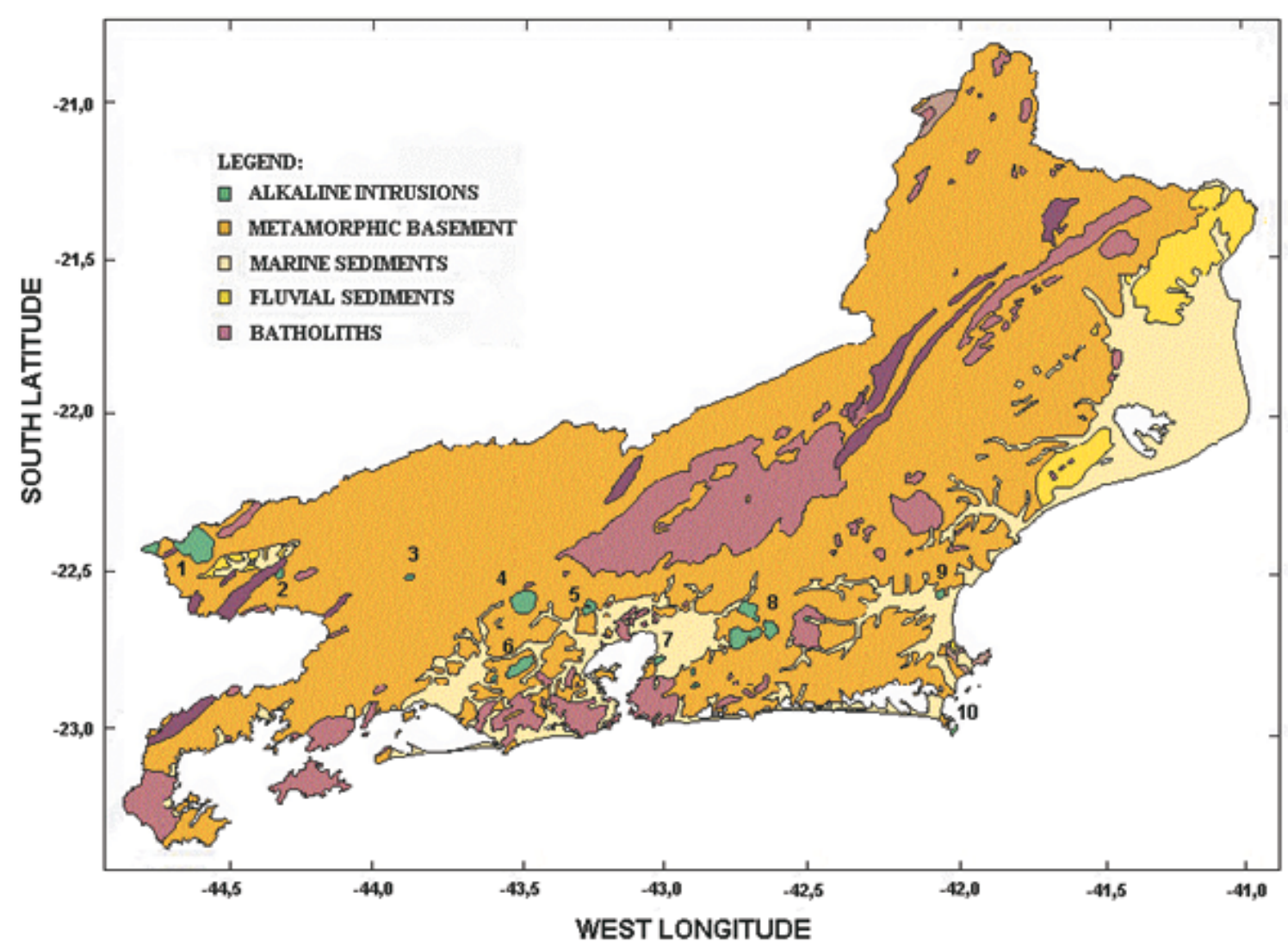

Figure 1 - Simplified geologic map of the state of Rio de Janeiro, adapted from Centro de Informações e Dados do Rio de Janeiro - CIDE (2002). The numbers indicate the main alkaline intrusions: 1 - Itatiaia; 2 - Resende; 3 - Pirái; 4 - Tinguá; 5 - Canaã; 6 - Nova Iguaçu; 7 - São Gonçalo; 8 - Rio Bonito; 9 - Morro de São João; 10 - Cabo Frio.

Mendanha and Madureira mountain belts, near the city of Rio de Janeiro.

\section{GEOTHERMAL GRADIENTS}

The efforts for determining geothermal gradients began with compilation of information on boreholes and wells drilled in the study area. In this stage, extensive use was made of the database for groundwater wells, set up by the Companhia de Pesquisa de Recursos Minerais - CPRM. The compilation of CPRM included data on over 4000 wells in the state of Rio de Janeiro. However, fewer than 1000 were found to have suitable technical conditions (depth range, casing pipes and well head protection) which could potentially guarantee success in eventual geothermal measurements. Nevertheless, subsequent field verifications revealed that a large part of this pre-selected set of wells is equipped with submersible pumps and currently being used for extracting groundwater. As a result successful temperature measurements could be carried out in fewer than 100 wells.
The thermal log data acquired in these wells were used in calculating geothermal gradients for 72 localities, distributed in 32 municipalities. The locations of the boreholes and wells where temperature data was acquired are indicated in Figure 2. The geographic distribution of the sites, is rather non-homogeneous, there being large variations in data density in the northern and eastern sectors of the study area.

\section{Field Measurements of Temperatures}

All temperature measurements reported in the present work were carried out using bead type thermistor sensors, having electrical resistances in the range of 10 to 50 kilo-ohms at room temperatures. The experimental setup for temperature logs consists essentially of a suitable sensor probe attached to an electrical resistancemeasuring device via a three-conductor cable. Auxiliary devices include a winch and a tripod for field operations. A six and a half digit precision multi-meter was used for measuring the electrical resistance of the sensor and of the cable. Use of three-conductor 


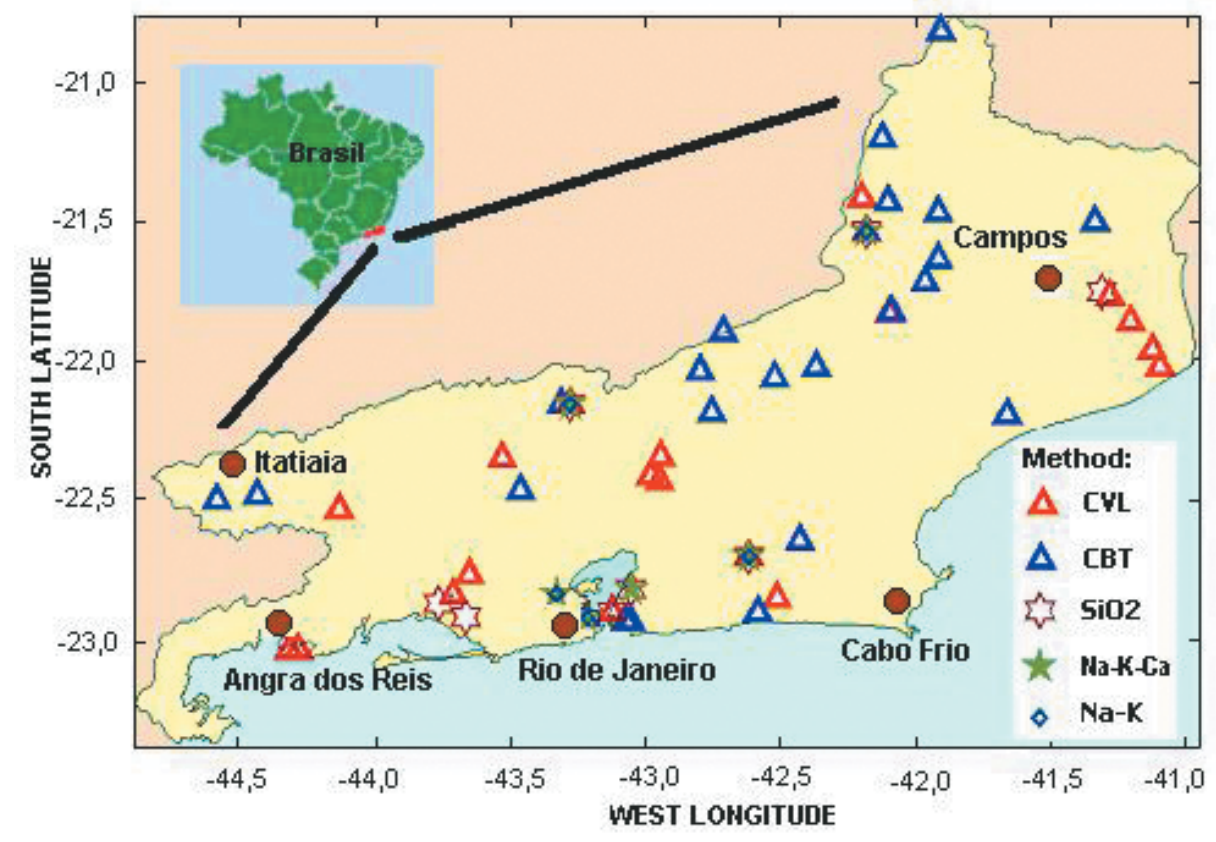

Figure 2 - Locations of geothermal measurements in the state of Rio de Janeiro. The symbols and letters in the inset indicates the methods used in the determination of geothermal gradients and heat flow. See text for details.

cable allowed corrections for the lead wire resistances of the cable itself. Power supply in the field for the multi-meter and the probe system was provided using a portable battery connected to a DCAC converter. Color coded markers on the cable were used in determination of the depth of the probe during log operations. The thermistor sensor is embedded in a small diameter waterproof metallic tube for protection against mechanical vibrations. This tube, made of copper and filled with thermally conductive cement, has a relatively short thermal response time (Roots, 1969). The relation between electrical resistance $(R)$ and absolute temperature $(T)$ of thermistor sensors is generally of the type:

$$
R=R_{0} e^{\left(B\left(\frac{1}{T}-\frac{1}{T_{0}}\right)\right)}
$$

where $R_{0}$ is the resistance at temperature $T_{0}$ and $B$ a constant characteristic of the sensor material. It is common practice to recast this equation in the form of a polynomial:

$$
\ln (R)=A+\frac{B}{T}+\frac{C}{T^{2}}+\ldots
$$

where $A, B, C$ are coefficients characteristic of the thermistor.

The probe system as a whole was calibrated both before and after field operations. During calibration tests the sensor probe is immersed in a temperature controlled water bath. A perforated metallic block inside the water bath was used for housing the probe. This block acts as a thermal damping device, filtering out high frequency fluctuations generated by the fluid circulation system of the thermostat. A standard platinum resistance thermometer (Presys-ST 501 with ITS 90 specifications) was used for measuring temperatures during calibration tests. The data obtained in calibration tests were employed in the determination of the coefficients (equation 2) of the thermistor response curve.

All measurements were carried out during down-going log operations, avoiding thereby perturbations generated by probe movements inside the borehole. In most cases, measurements were carried out at two meter intervals. This was considered appropriate for the present work, in view of the limitations arising from the sensitivity of the probe and of the time spent in field operations. The time interval between positioning of the probe and the final reading was set at 30 to 120 seconds, depending on the thermal stability conditions of the temperature field in the borehole.

\section{Determination of Geothermal Gradients}

Four different methods were employed in determining thermal gradients, depending on the characteristics of primary data. These are designated here as the conventional (CVL), conventional bottom temperature (CBT), aquifer temperature (AQT) and geochemical (GCL) methods. We provide here only a very brief description of the principles of these methods. Further details of the metho- 
dology and examples of applications are discussed in detail by Hamza \& Muñoz (1996), Gomes \& Hamza (2003), and Hamza et al. (2005b).

The measured values of temperatures need to be corrected for the presence of thermal perturbations. The changes in vegetation cover and climate conditions of the recent past are known to have significant influence on the temperature field at shallow depths. Incorporation of such corrections are based on models of surface temperature changes and are well-known in the relevant literature (see for example: Hamza, 1991; Shen \& Beck, 1991; Hamza, 1998; among others). In the present case, climate corrections proposed for the state of Rio de Janeiro by Cerrone \& Hamza (2003) were adopted. Temperature variations accompanying elevation changes also affect the determination of thermal gradients (Bullard, 1954; 1965). However, calculations carried out by Gomes (2004) indicate that the topographic corrections are significant only for six localities, situated in the mountainous regions in the northern part of the study area. The corrections for the effect of thermal disturbances in bore holes, induced by drilling operations, are generally significant only for time periods comparable to the duration of drilling activity (Lachenbruch \& Brewer, 1959). In the present case, the elapsed times between conclusion of drilling and temperature log operations were several orders of magnitude larger compared to the periods for drilling shallow wells. Only in one case the corrections for drilling disturbances were found to be significant.

The conventional (CVL) method was employed in cases where the bore holes were found to be in thermal equilibrium and it was possible to identify linear sections in temperature logs indicative of heat transfer by conduction. The temperature gradient was determined by least square fit to log data from selected depth intervals. The details of the least square techniques are available in standard text books on data analysis (see for example, Bevington, 1969) and its use for determination of temperature gradients in bore holes has been discussed by Araújo (1978). The choice of the depth interval was based on log data and on information from lithologic profiles on the characteristics of the rock types encountered. Example of temperature profiles obtained by the conventional method is illustrated in Figure 3. A summary of geothermal gradients and intercept values obtained by this method is provided in Table 1, along with estimates of the errors (standard deviations in the least square fits) involved. The gradient values obtained are found to fall in the range of 15 to $30^{\circ} \mathrm{C} / \mathrm{km}$.

In some cases the results of temperature logs reveal that the thermal field of the well is disturbed by water flows occurring in its interior. In such cases the direct use of the conventional method turns out to be impractical for determination of temperature gradients. Nevertheless, an estimate of the gradient may be obtained using temperature data from the bottom-most part of the bore hole where hydraulic perturbations induced by in-hole flows are practically absent. This procedure, designated here as the conventional bottom temperature method - CBT, require knowledge of the mean annual temperature of the surface. In the present case, the temperature data reported for the state of Rio de Janeiro by the Ministry of Agriculture (Ministério de Agricultura, 1969) was used. The principle of operation of the CBT method is essentially the same as that of the well-known BHT method, employed in estimating temperature gradients in oil wells. The main difference is that in the CBT method the bottom temperatures can be determined with a much greater degree of accuracy than is possible in the BHT method employed in oil well measurements. In addition, high precision repeat measurements may easily be carried out, to verify the nature of drilling disturbances. The results of CBT method are however sensitive to errors in the value of the mean annual surface temperature. Details of the use of this method have been discussed by Ribeiro (1987). Examples of temperature profiles obtained by this method are illustrated in Figure 4 and a summary of CBT gradients is provided in part (a) of Table 2. Note that the gradient values by the CBT method are also found to fall in the range of 15 to $30^{\circ} \mathrm{C} / \mathrm{km}$, in relatively close agreement with those obtained using the conventional method.

In many of the groundwater wells the presence of in-hole submersible pumps does not allow temperature log operations. In such cases an estimate of the gradient may be obtained on the basis of temperatures measured during pumping tests. Santos et al. (1986) provides details of the use of this method (designated here as the aquifer temperature method - AQT) for determination of temperature gradients in artesian wells of the Paraná basin. The temperature of the pumped water needs to be corrected for the effects of radial heat loss during up-flow of fluids. The principle of this correction is based on a model of heat loss in cylindrical conduits, proposed originally by Bolditzar (1958). The model assumes that water is being drawn from a single confined aquifer and the temperature of the pumped water is not affected by eventual mixing of cold waters in the upper parts of the well. The overall heat loss during up-flow of water depends on the depth of the aquifer, the flow rate and the thermal properties of the wall rocks. Usually the depth of the aquifer is known from drilling operations and the flow rate is determined from pumping tests. If, in addition, data for determining the mean annual surface temperature is available it is possible to obtain an estimate of the temperature gradient. A summary of geothermal gradient values obtained by 


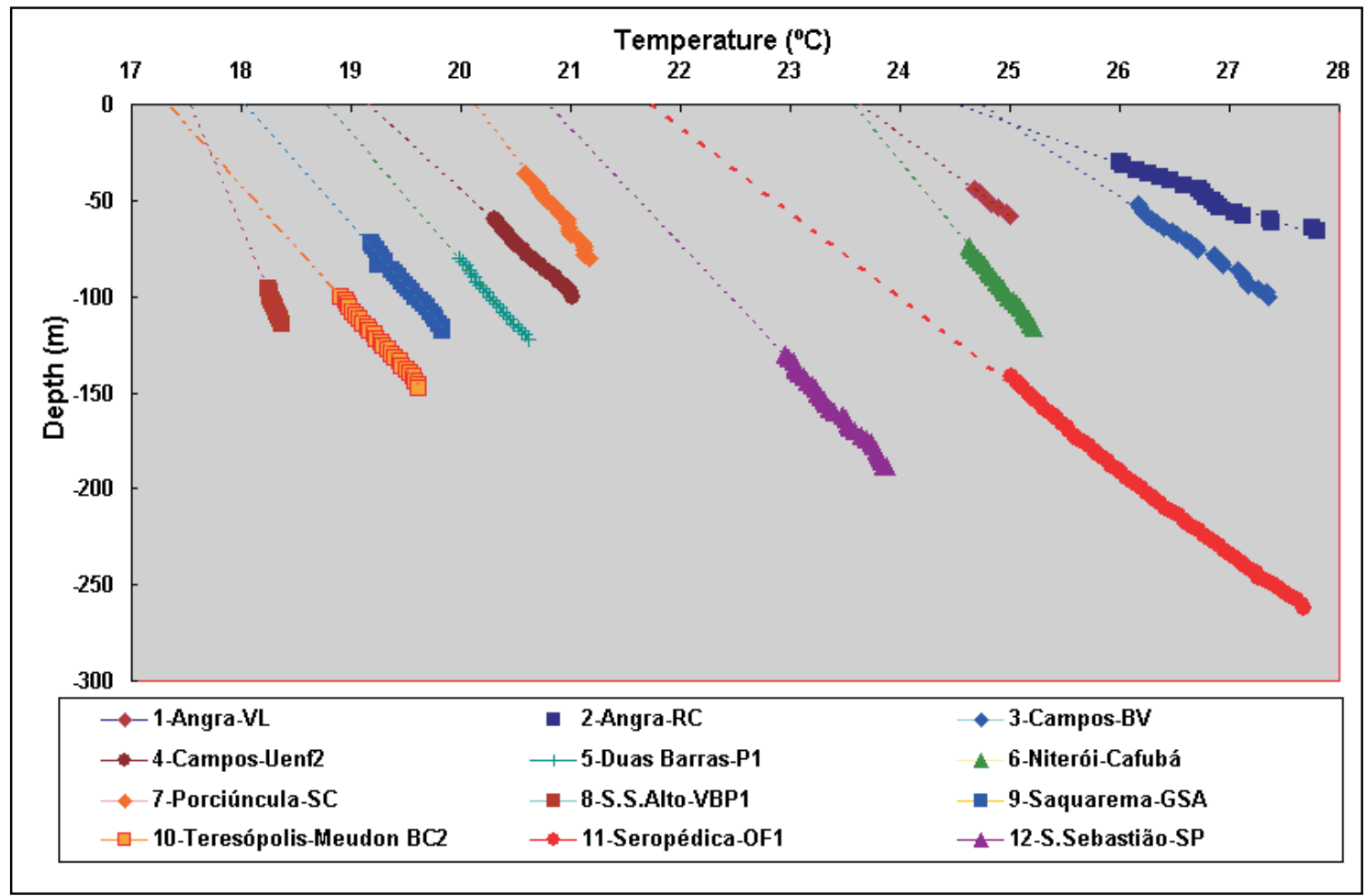

Figure 3 - Examples of linear segments of temperature profiles used in the determination of geothermal gradients by the conventional (CVL) method. The bottom inset refers to locations of geothermal measurements.

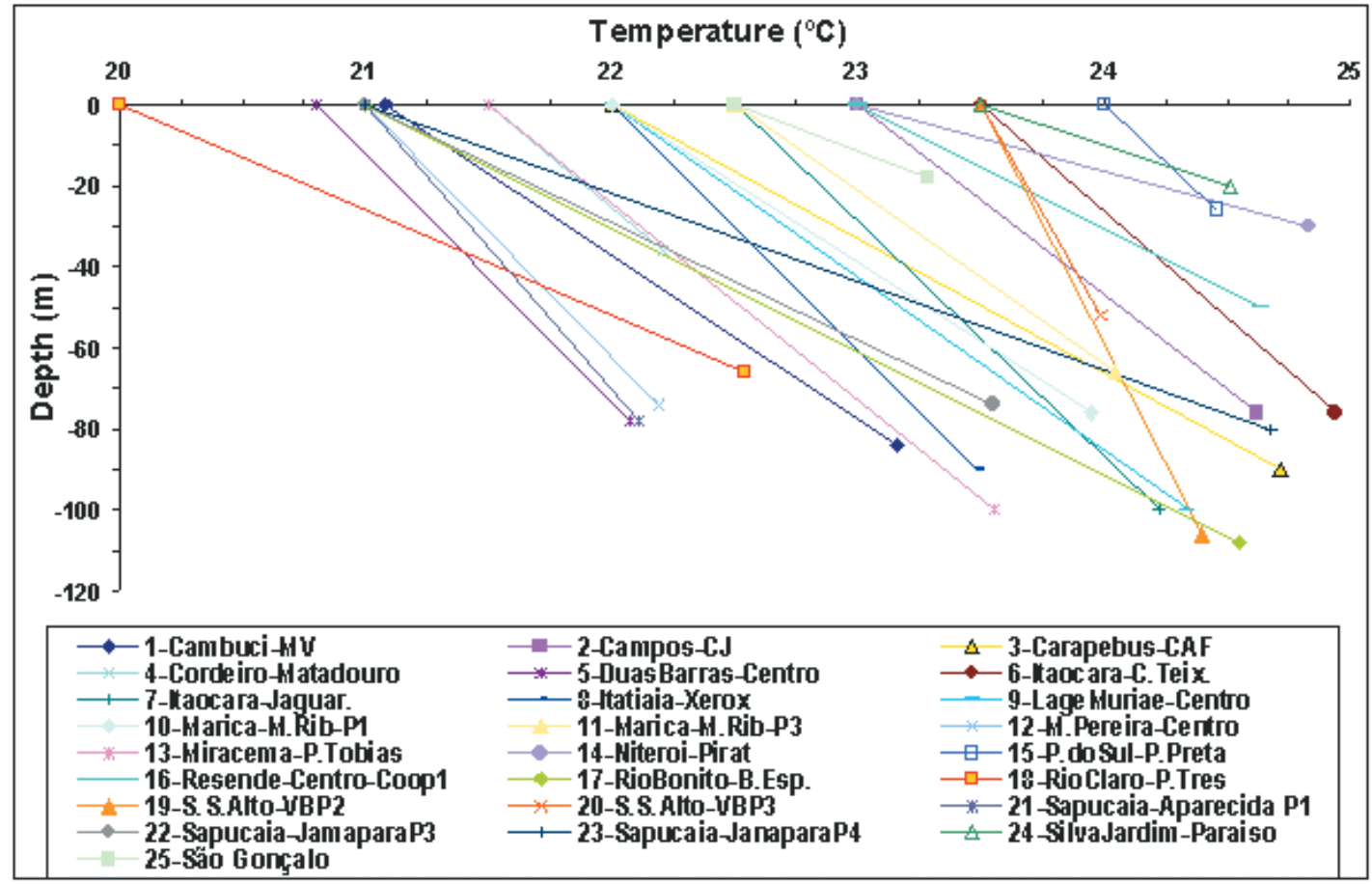

Figure 4 - Examples of inferred linear segments of undisturbed temperature profiles, proposed on the basis of the conventional bottom temperature method (CBT). The inset refers to locations of geothermal measurements. See text for details. 
Table 1 - Results of geothermal gradients by the conventional method (CVL). $N$ is the number of temperature measurements and $\sigma$ the standard deviation.

\begin{tabular}{|l|l|l|l|l|l|c|c|}
\hline \multirow{2}{*}{ Municipality } & \multirow{2}{*}{ Locality/Well } & \multicolumn{2}{|c|}{ Coordinates } & \multirow{2}{*}{$N$} & \multirow{2}{*}{ Depth $(\mathrm{m})$} & \multicolumn{2}{|c|}{ Gradient $\left({ }^{\circ} \mathrm{C} / \mathrm{km}\right)$} \\
& & Latitude & Longitude & & & Mean & $\sigma$ \\
\hline Angra dos Reis & Bonfim & 23.0333 & 44.2833 & 33 & 66 & 41 & 2.0 \\
\hline & Virada Leste & 23.0333 & 44.3167 & 31 & 60 & 23 & 1.1 \\
\hline Campos & Baixa Grande & 21.9578 & 41.9197 & 55 & 108 & 19 & 1.9 \\
\hline & Boa Vista & 22.0183 & 41.1322 & 50 & 100 & 26 & 0.5 \\
\hline & UENF2 & 21.7636 & 41.2864 & 51 & 100 & 19 & 0.3 \\
\hline Duas Barras & DBP1 & 22.0547 & 42.5203 & 62 & 122 & 15 & 0.2 \\
\hline & DBP2 & 22.0547 & 42.5203 & 34 & 66 & 15 & 0.1 \\
\hline & DBP3 & 22.0547 & 42.5206 & 40 & 78 & 17 & 2.6 \\
\hline Maricá & M. Ribeiro & 22.0547 & 42.5206 & 50 & 98 & 20 & 0.0 \\
\hline Miracema & Centro & 21.4167 & 42.2000 & 38 & 78 & 20 & 0.5 \\
\hline Niterói & Cafubán & 22.9325 & 43.0672 & 59 & 116 & 14 & 0.1 \\
\hline Paraíba do Sul & C. das AlmaS & 22.1500 & 43.3167 & 51 & 100 & 17 & 0.0 \\
\hline Porciúncula & Santa Clara & 20.8211 & 41.9094 & 41 & 80 & 13 & 0.4 \\
\hline Resende & Centro & 22.4833 & 44.4333 & 26 & 32 & 34 & 1.7 \\
\hline & D.Maria & 22.4833 & 44.4333 & 26 & 50 & 26 & 2.0 \\
\hline Rio Claro & Passa Três & 22.6667 & 44.0333 & 34 & 66 & 24 & 0.5 \\
\hline Saquarema & Gj. S. Antonio & 22.8489 & 42.5122 & 60 & 118 & 15 & 0.3 \\
\hline S. Seb. do Alto & V.Barro Centro & 21.8231 & 42.0994 & 59 & 114 & 7.6 & 0.1 \\
\hline Seropédica & Orfanato & 22.7661 & 43.6542 & 136 & 262 & 15 & 0.1 \\
\hline & P. S. Piranema & 22.8356 & 43.7131 & 61 & 120 & 23 & 1.8 \\
\hline Teresópolis & FVM & 22.4331 & 42.9444 & 69 & 134 & 21 & 0.0 \\
\hline & Faz. Texas & 22.3442 & 42.9403 & 44 & 68 & 22 & 0.0 \\
\hline Vassouras & BC2 & 22.4331 & 42.9444 & 75 & 148 & 16 & 0.2 \\
\hline Volta Redonda & Masra Imbui & 22.4142 & 42.9783 & 51 & 100 & 21 & 0.0 \\
\hline & Padre Josimo & 22.5333 & 44.1333 & 22 & 70 & 20 & 0.3 \\
\hline
\end{tabular}

this method is given in part (b) of Table 2. Again, the gradient values are found to fall in the range of 15 to $30^{\circ} \mathrm{C} / \mathrm{km}$, in reasonably good agreement with those obtained using CVL and CBT methods.

In localities of thermal springs, it is common practice to employ indirect methods of estimating temperature gradients. Generally techniques of geochemical thermometry are employed in obtaining estimates of the temperature of the deep thermal reservoir. The basic assumption in this approach is that the dissolution of some of the elements in thermal waters is directly related to the reservoir temperature. Fournier (1981) provides a summary of appropriate relations for the dissolution of Silica, Sodium, Potassium and Calcium. These have come to be known popularly as 'geochemical thermometers', and are used extensively in assessment of deep temperatures in hydrothermal systems. The reser- voir temperature determined in this manner may be combined with the surface temperature in estimating gradients. This approach is usually designated as the geochemical (GCL) method. Hurter et al. (1983) and Hurter (1987) made use of this method in estimating temperature gradients for some of the geothermal areas of Brazil.

In the earlier work of Hurter (1987) reservoir temperatures were calculated based on the relations proposed by Fournier (1981). In the present work the temperatures were calculated based on the modified equations developed by Giggenbach (1988) as well as the empirical relations proposed by Verma \& Santoyo (1995). A summary of geothermal gradients obtained by this method is provided in Table 3 for the Silica, Na-K and Na-K-Ca geothermometers. Note that most of the gradient values fall in the interval of 30 to $75^{\circ} \mathrm{C} / \mathrm{km}$, which is higher than the range of 
Table 2 - Results of geothermal gradients by (a) the conventional bottom temperature (CBT) and (b) the aquifer temperature (AQT) methods. $\sigma$ is the standard deviation.

(a) - Geothermal gradient values calculated using the CBT method.

\begin{tabular}{|c|c|c|c|c|c|c|}
\hline \multirow{2}{*}{ Municipality } & \multirow{2}{*}{ Locality/Well } & \multicolumn{2}{|c|}{ Coordinates } & \multirow{2}{*}{ Depth(m) } & \multicolumn{2}{|c|}{ Gradient ( $\left.{ }^{\circ} \mathrm{C} / \mathrm{km}\right)$} \\
\hline & & Latitude & Longitude & & Mean & $\sigma$ \\
\hline Cambuci & Monte Verde & 21.4664 & 41.9197 & 84 & 25 & 2.0 \\
\hline \multirow[t]{2}{*}{ Campos } & Consel. Josino & 21.5006 & 41.3419 & 76 & 21 & 1.1 \\
\hline & S. Sebastião & 21.8539 & 41.2111 & 76 & 37 & 1.9 \\
\hline Carapebus & Centro & 22.1869 & 41.6656 & 90 & 30 & 0.5 \\
\hline Cordeiro & Matadouro & 22.0169 & 42.3689 & 36 & 34 & 0.3 \\
\hline Duas Barras & DBP4 & 22.0547 & 42.5203 & 78 & 16 & 0.2 \\
\hline \multirow[t]{2}{*}{ Itaocara } & Cel. Teixeira & 21.6333 & 41.9197 & 76 & 19 & 0.1 \\
\hline & Jaguarembé & 21.7133 & 41.9667 & 100 & 17 & 2.6 \\
\hline Itatiaia & Xerox2 & 22.5000 & 44.5833 & 90 & 17 & 0.1 \\
\hline Laje de Muriaé & Centro & 21.2028 & 42.1250 & 100 & 23 & 0.5 \\
\hline \multirow[t]{2}{*}{ Maricá } & Manoel Ribeiro & 22.9014 & 42.5833 & 76 & 26 & 0.1 \\
\hline & Manoel Ribeiro & 22.9014 & 42.5833 & 66 & 20 & 0.1 \\
\hline Miguel Pereira & Centro & 22.4667 & 43.4667 & 74 & 16 & 0.4 \\
\hline Miracema & Paraíso Tobias & 21.4167 & 42.2000 & 100 & 21 & 1.7 \\
\hline Niterói & Piratininga & 22.9303 & 43.0500 & 30 & 28 & 2.0 \\
\hline Paraíba do Sul & Ponte Preta & 22.1500 & 43.3167 & 26 & 18 & 0.5 \\
\hline Resende & Centro & 22.4833 & 44.4333 & 50 & 33 & 0.3 \\
\hline Rio Bonito & Boa Esperança & 22.7931 & 42.5372 & 108 & 33 & 0.1 \\
\hline São Gonçalo & Tribobó & 22.8500 & 43.0500 & 18 & 30 & 0.1 \\
\hline \multirow[t]{2}{*}{ S.S. do Alto } & V.Barro-Centro & 21.8211 & 42.0922 & 106 & 09 & 1.8 \\
\hline & V.Barro-Centro & 21.8242 & 42.0983 & 52 & 07 & 0.1 \\
\hline \multirow[t]{3}{*}{ Sapucaia } & Aparecida & 22.0322 & 42.7950 & 78 & 14 & 0.1 \\
\hline & Jamapara P3 & 21.8947 & 42.7106 & 74 & 14 & 0.2 \\
\hline & Jamapara P4 & 21.8953 & 42.7086 & 80 & 21 & 0.1 \\
\hline
\end{tabular}

(b) - Geothermal gradient values calculated using the AQT method.

\begin{tabular}{|c|c|c|c|c|c|c|}
\hline \multirow{2}{*}{ Municipality } & \multirow{2}{*}{ Locality/Well } & \multicolumn{2}{|c|}{ Coordinates } & \multirow{2}{*}{ Depth(m) } & \multicolumn{2}{c|}{ Gradient $\left({ }^{\circ} \mathrm{C} / \mathrm{km}\right)$} \\
\cline { 3 - 4 } \cline { 6 - 7 } & & Latitude & Longitude & & Mean & $\sigma$ \\
\hline Teresópolis & Água Quente & 22.1786 & 42.7525 & 20 & 64 & 11.1 \\
\hline Campos & São Sebastião & 21.8539 & 41.2111 & 76 & 35 & 7.7 \\
\hline Cordeiro & Cordeiro & 22.0169 & 42.3689 & 36 & 19 & 5.6 \\
\hline
\end{tabular}

gradient values obtained using the CVL, CBT and AQT methods.

\section{Quality Considerations of the Methods used for Temperature Gradients}

The quality considerations of the available data set are, in part, related to the characteristics of the methods used for determining gradients, which in turn depend on the nature and availability of primary temperature data. In an attempt to minimize problems arising from the use of data sets of mixed quality Hamza \& Muñoz
(1996) employed a priority scheme, based on qualitative considerations of the relative advantages and disadvantages of the various methods. A similar procedure was also adopted in the present work. Thus data obtained by conventional (CVL) method, which make use of measured values of temperatures at several well determined depths was given the highest priority. The CBT method, because of its inherent merits over those of the AQT and GCL methods, is considered to be the second best option. A rigorous test of the reliability of CBT method would require compa- 
Table 3 - Estimates of geothermal gradients based on the geochemical (GCL) method for the Silica (a), Na-K (b) and Na-K-Ca (c) geothermometers. $\sigma$ represents the standard deviation.

(a) - Estimates using the Silica thermometer $\left(\mathrm{SiO}_{2}\right)$

\begin{tabular}{|c|c|c|c|c|c|}
\hline \multirow{2}{*}{ Municipality } & \multirow{2}{*}{ Locality/Spring } & \multicolumn{2}{|c|}{ Coordinates } & \multicolumn{2}{c|}{ Gradient $\left({ }^{\circ} \mathrm{C} / \mathrm{km}\right)$} \\
\cline { 3 - 6 } & & Latitude & Longitude & Mean & $\sigma$ \\
\hline Campos & Pedra Alecrim & 21.7500 & 41.3167 & 34 & 0.4 \\
\hline Itaguaí & Poço 2 & 22.8667 & 43.7667 & 49 & 0.3 \\
\hline Niterói & Ingá & 22.8961 & 43.1203 & 60 & 0.3 \\
\hline Paraíba do Sul & Salutaris & 22.1500 & 43.2833 & 46 & 0.3 \\
\hline Rio Bonito & Catimbau & 22.7000 & 42.6167 & 69 & 0.2 \\
\hline Rio de Janeiro & Santa Cruz & 22.9167 & 43.2167 & 29 & 0.2 \\
\hline St. A. de Pádua & Iodetada & 21.5333 & 42.1833 & 45 & 0.2 \\
\hline S. Gonçalo & Ag. S. Gonçalo & 22.8167 & 43.0500 & 51 & 0.3 \\
\hline
\end{tabular}

(b) - Estimates using the Sodium - Potassium thermometer (Na-K).

\begin{tabular}{|c|c|c|c|c|c|}
\hline \multirow{2}{*}{ Municipality } & \multirow{2}{*}{ Locality/Spring } & \multicolumn{2}{|c|}{ Coordinates } & \multicolumn{2}{c|}{ Gradient $\left({ }^{\circ} \mathrm{C} / \mathrm{km}\right)$} \\
\cline { 3 - 6 } & & Latitude & Longitude & Mean & $\sigma$ \\
\hline Paraíba do Sul & Salutaris & 22.1500 & 43.2833 & 26 & 8.4 \\
\hline Rio Bonito & Catimbau & 22.7000 & 42.6167 & 69 & 7.2 \\
\hline Rio de Janeiro & Água Meyer & 22.6667 & 43.5833 & 70 & 7.4 \\
\hline & Nazareth & 22.9167 & 43.2167 & 57 & 7.3 \\
\hline & Silva Manuel & 22.9167 & 43.2167 & 24 & 5.3 \\
\hline St. A. de Pádua & Iodetada & 21.5333 & 42.1833 & 31 & 5.8 \\
\hline
\end{tabular}

(c) - Estimates using the Sodium-Potassium-Calcium thermometer (Na-K-Ca).

\begin{tabular}{|c|c|c|c|c|c|}
\hline \multirow{2}{*}{ Municipality } & \multirow{2}{*}{ Locality/Spring } & \multicolumn{2}{|c|}{ Coordinates } & \multicolumn{2}{c|}{ Gradient $\left({ }^{\circ} \mathrm{C} / \mathrm{km}\right)$} \\
\cline { 3 - 6 } & & Latitude & Longitude & Mean & $\sigma$ \\
\hline Paraíba do Sul & Salutaris & 22.1500 & 43.2833 & 41 & 1.3 \\
\hline Rio Bonito & Catimbau & 22.7000 & 42.6167 & 69 & 1.8 \\
\hline Rio de Janeiro & Água Meyer & 22.6667 & 43.5833 & 64 & 1.7 \\
\hline & Silva Manuel & 22.9167 & 43.2167 & 29 & 1.4 \\
\hline St. A. de Pádua & Iodetada & 21.5333 & 42.1833 & 45 & 1.4 \\
\hline S. Gonçalo & Ag. S. Gonçalo & 22.8167 & 43.0500 & 51 & 1.5 \\
\hline
\end{tabular}

rative analyses of repeat temperature logs, carried out before and after blockage of hydraulically active fracture zones in bore holes. However, cementing operations capable of blocking in-hole flows are expensive and not practical in many cases. Hamza et al. (2005b) suggested a relatively simple procedure that provides indirect checks on the reliability of this method. In this case, a comparison is made of the gradient values by the CBT method with those obtained by the conventional (CVL) method for undisturbed bore holes, situated in the same general region as that of the boreholes with hydraulic disturbances. According to Hamza et al. (2005b) the use of CBT method leads to errors of less than $4 \%$ in the determination of gradients in the interval of 5 to $50^{\circ} \mathrm{C} / \mathrm{km}$.
In the AQT method essentially, the measured wellhead temperatures are corrected using an appropriate model to account for the radial heat loss during up-flow of fluids. Santos et al. (1986) made a comparative analysis of the results by the AQT method with those by the conventional and BHT methods and concluded that differences in gradient values are less than $5 \%$, for the wells located in the Paraná basin. More recently, Hamza et al. (2005b) compared temperatures measured in wells under artesian flow conditions with those calculated following the procedure of Santos et al. (1986) as part of an independent check on the reliability of AQT method. In this case, errors in aquifer temperatures by the AQT method were found to be less than $1 \%$ while those for gradi- 
ents are less than $2 \%$. For the purposes of the present work, the results of these comparisons were considered as satisfactory and the AQT method is classified as occupying the third position in the priority list.

The results of geochemical methods, when compared with those of the other methods, appear to provide overestimates of the temperature gradients. It is, however, likely that the localities of thermal springs, being discharge areas of thermal fluids, are inherently characterized by relatively higher thermal gradients. Measurements in deep holes using conventional methods are necessary to understand the true nature of thermal field in localities of thermal springs. Another major source of uncertainty in GCL methods arises from the methods used in estimating the depth of circulation of thermal fluids. These estimates are usually based on inferences as to the structural setting of the crustal blocks and of the aquifers. Because of such inherent uncertainties the results of the geochemical (GCL) method has been assigned the least priority. The estimates by geochemical method are taken into consideration only for localities where other more reliable methods have failed to provide satisfactory results.

Analysis of data presented in Tables 1 to 3 reveal that there is considerable variability in local geothermal gradients. Such variability may arise either as a result of advective heat transport by subsurface fluid flows or as a consequence of local thermal refraction effects. Preliminary calculations indicate that the effects of thermal refraction are unlikely to be significant, except in very specific cases of structural complexity. On the other hand, there are indications of the existence of water flow at shallow depths in many localities. Detailed information on groundwater flow pattern is however necessary to evaluate the role of advective heat transfer on local and regional scales.

\section{Local and Regional Variations in Geothermal Gradients}

As noted earlier, the temperature gradients obtained by the CVL method are in reasonable agreement with those found for the CBT and AQT methods. On the other hand, the estimates of gradients obtained by the GCL method are found to fall in a slightly higher range. The possible existence of systematic difference between the GCL and the other methods is a matter of concern and makes the interpretation of regional distribution a difficult task. To circumvent this problem, two different data sets were considered: first one based exclusively on the relatively more reliable $\mathrm{CVL}$, CBT and AQT data and a second one of mixed quality that include also the GCL data.
Maps of the regional distribution of temperature gradients were produced using both commercially available (SURFER) and public domain (GMT) automatic contouring programs. The software routines available in these graphic utility packages were employed in testing a variety of schemes for grid spacing, data interpolation and contouring procedures. The regional geothermal gradient map based on the CVL, CBT and AQT data sets is presented in Figure 5. It reveals that the temperature gradients are low to normal (in the range of 10 to $30^{\circ} \mathrm{C} / \mathrm{km}$ ) mainly in the eastern parts of the state of Rio de Janeiro. On the other hand, gradient values higher than $30^{\circ} \mathrm{C} / \mathrm{km}$ are found in the western parts. The distinct difference in the distribution of thermal gradients between the eastern and western parts of the study area may be considered as an important feature of the regional geothermal field.

In some localities such as Niterói, São Gonçalo, Jamapará (Sapucaia), Água Quente and Silva Jardim the gradients are found to be higher than $50^{\circ} \mathrm{C} / \mathrm{km}$. These values appear as isolated anomalies and are based on measurements carried out in very shallow wells. In the absence of supplementary data from deep wells we consider it as unwise to attach overdue significance to such observations.

The regional gradient map for the mixed data set which includes also the estimated values by the GCL method is presented in Figure 6 . In this case temperature gradients with values higher than $30^{\circ} \mathrm{C} / \mathrm{km}$ are found to occur over a much larger area. It is important to note that many of the high gradient areas are coincident with the localities of thermal and mineral springs. There are, however, indications of an approximate east - west trend in the gradient anomaly, which is nearly coincident with the belt of alkaline intrusions of Tertiary age.

\section{THERMAL CONDUCTIVITY MEASUREMENTS}

Rock samples obtained from 72 localities were used in thermal conductivity measurements. There were, however, considerable variations in the physical characteristics of these samples, which were taken into consideration in selecting the experimental technique employed. In the western parts of the study area solid cores recovered from boreholes in drilling operations were available, while in the eastern parts of the study area samples available were mostly drill cuttings. The acquisition of core samples from the remaining parts of the study area turned out to be a difficult task, since these were not available for many of the water wells drilled prior to 1990. Neither the owners of the wells nor the state authorities have a program for long term preservation of the drill cuttings. 


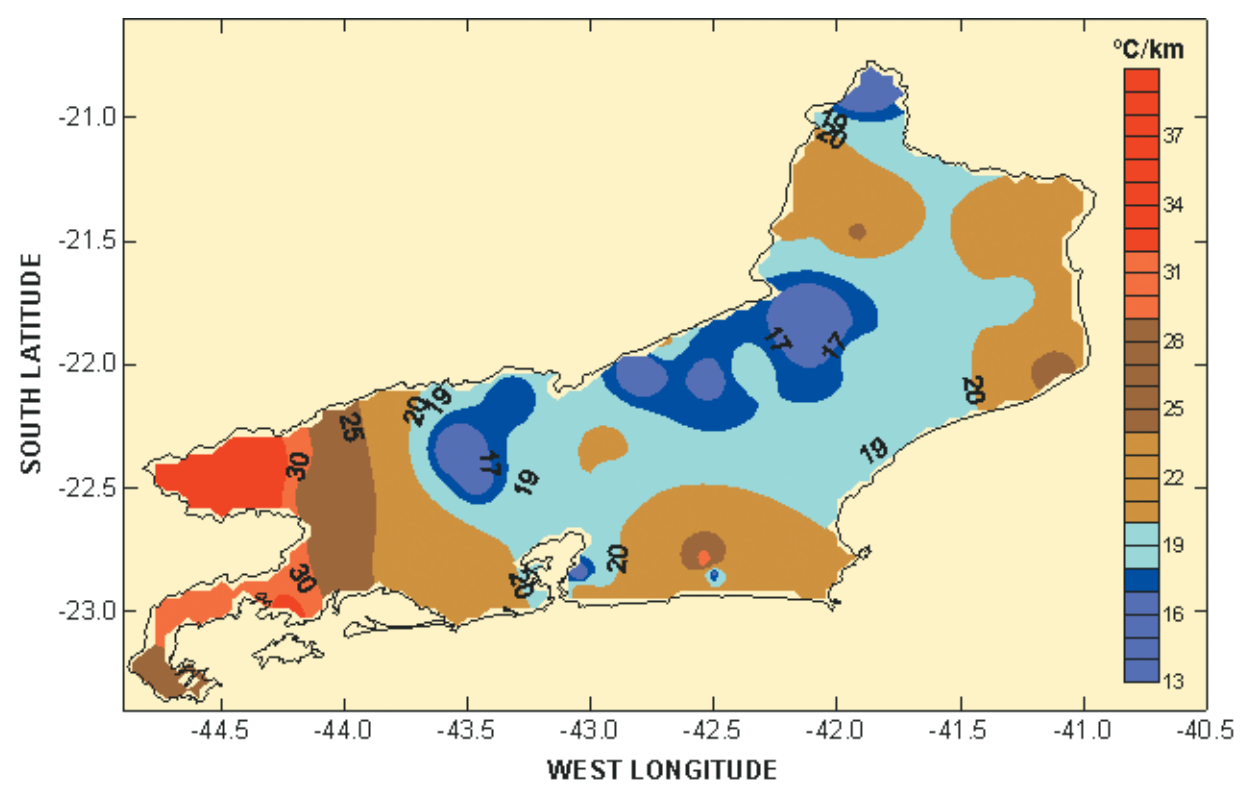

Figure $\mathbf{5}$ - Regional distribution of geothermal gradients based on selected data sets (CVL, CBT and AQT methods). See text for details.

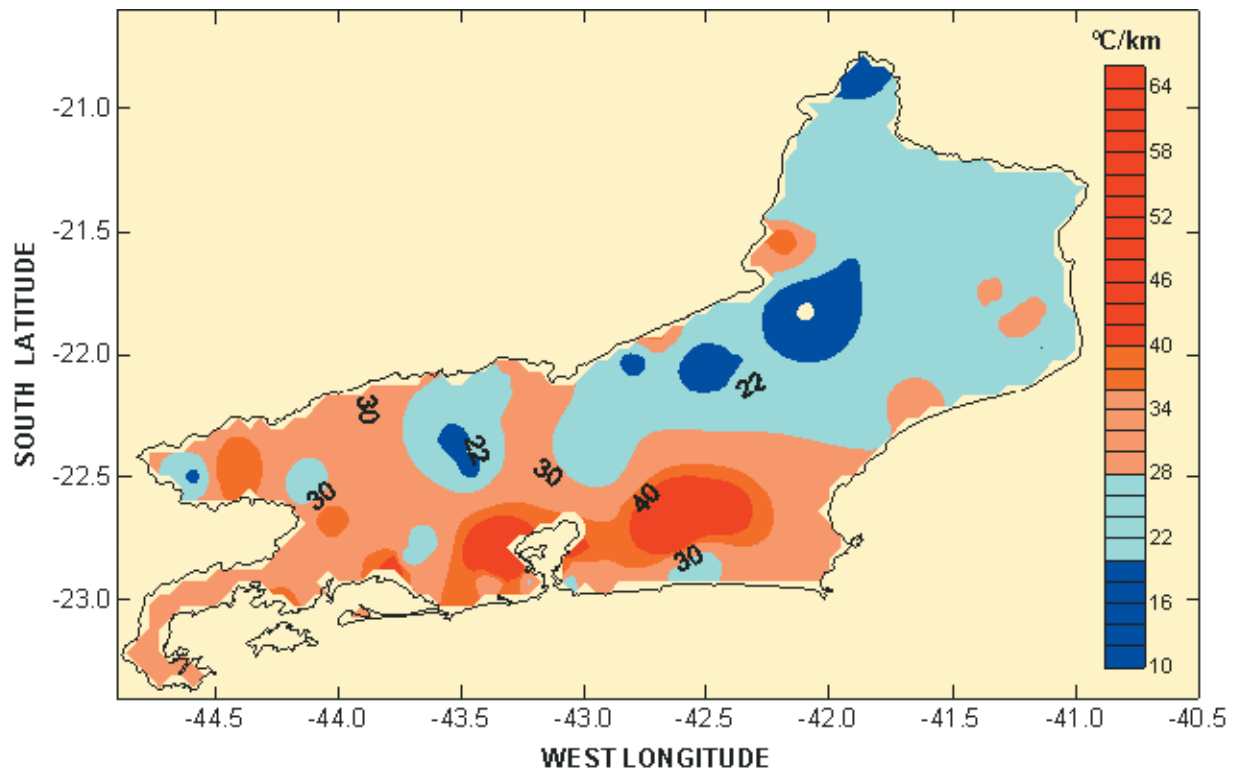

Figure 6 - Regional distribution of geothermal gradients based on the complete data set that include also estimates by the GCL method.

In many cases, drilling operations were completed during the decades of 1970 and 1980 and this also contributed to difficulties in obtaining representative samples. In an attempt circumvent such problems fresh unaltered samples taken from outcrops of the main geologic formations were used as supplementary material for thermal conductivity measurements. The sample collection was carried out by the Geology Department of the State University of Rio de Janeiro (UERJ). The localities from which samples were ob- tained for conductivity measurements are indicated in the map of Figure 7 . The sites of outcrops are not always close to the localities of gradient data, a consequence of problems encountered in acquisition of representative samples of the geologic formations.

\section{Experimental Procedures}

Most of the thermal conductivity measurements were carried out using the facilities available at the Geothermal Laboratory of the 


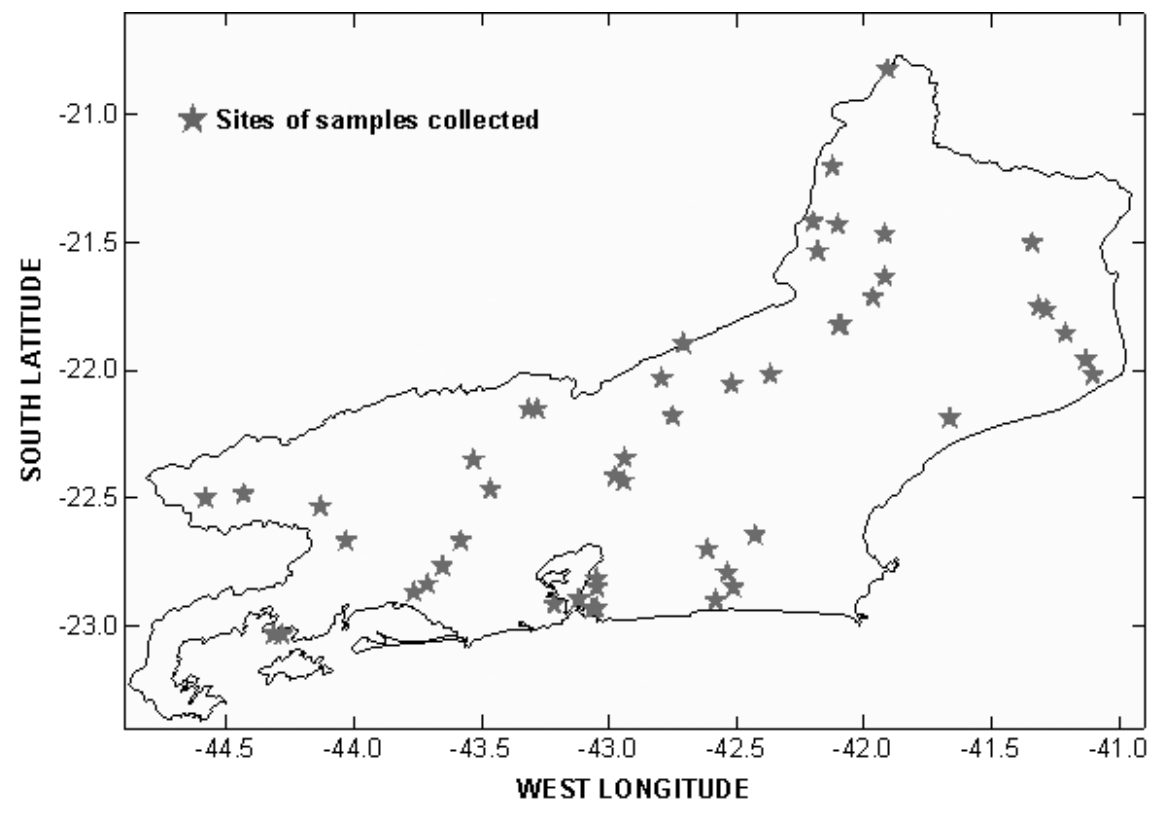

Figure 7 - Map indicating sites of samples used for thermal conductivity measurements.

Observatório Nacional - ON. Two different experimental techniques were employed, designated here as the line source and the plane source methods. These are in fact transient methods where the thermal conductivity is evaluated by monitoring the growth and decay of thermal perturbations induced in the sample. The principle of the line source method is well known (see for example, Carslaw \& Jaeger, 1959) and its application for measurements with geologic materials in Brazil has been discussed in detail by Hamza et al. (1980) and Marangoni (1986). The sensor probes of the line source method allow two different heat dissipation geometries, depending on the physical characteristics of the samples. For measurements in unconsolidated materials the probe is inserted into the sample. In this case the dissipation of heat then occurs in what is termed as the full-space or $4 \pi$ geometry. In the case of solid cores and consolidated materials, the probe of line source is glued onto the smooth surface of a reference plate and brought into contact with a smooth surface of the sample. If the reference plate is a thermal insulator the heat dissipation is considered as occurring under what is termed as half-space or $2 \pi$ geometry. The experimental setup used in the line source methods is similar to the ones employed in earlier studies by Hamza et al. (1980) and Marangoni (1986).

The use of experimental devices employing plane sources of heat, operating under transient thermal regime, is less frequent. Carslaw \& Jaeger (1959) discuss the theory of the plane source method in detail. The temperature $(T)$ variation at a distance $(x)$ with time $(t)$ of a sample of thermal conductivity $(\lambda)$ in contact with a continuous plane source of heat is given by:

$$
T=Q\left(\frac{t \rho c}{\pi \lambda}\right)^{1 / 2} e^{-\frac{\left(x-x^{\prime}\right)^{2}}{4 \kappa t}}-\frac{Q\left|x-x^{\prime}\right|}{2 \kappa \rho c} \operatorname{erfc} \frac{\left|x-x^{\prime}\right|}{2 \sqrt{\kappa t}}
$$

where $Q$ is the strength of heat source, $(\rho C)$ the heat capacity and $\kappa$ the thermal diffusivity. Mongelli (1968) reported results of experimental studies on rock samples using this method. In the present work, a commercially available instrument (ISOMET 104, Applied Precision Ltd., Slovak Republic) was used. It is equipped with a microprocessor device, which carries out integration of the time - temperature curves and provides a display of the calculated value of thermal conductivity. Integration of the thermal response is carried out during both the heating and cooling cycles.

Both primary and secondary standards were used in calibrating the measurement devices. The primary standards used are fused silica and crystalline quartz discs. These are usually considered as reference materials with internationally accepted values of thermal conductivity. The secondary standards include selected engineering materials and discs of rock samples whose thermal conductivity values are known from inter-laboratory comparison studies.

\section{Variation with Rock Types}

The results of experimental measurements of thermal conductivity were used in determining representative values for the main geological formations and rock types. First, a simplified analysis was 
carried out in which the mean values of the main geologic formations were determined. The procedure adopted in this case relies not only on the use of experimental data but also on information available in detailed geologic maps of the localities. Thus weighted mean values of thermal conductivity of the main geologic formations occurring within the study area were calculated. The set of such values, reproduced in Table 4, reveal that the geologic formations of Neoproterozoic age are characterized by mean thermal conductivity values in the range of 2.7 to $3.0 \mathrm{Wm}^{-1} \mathrm{~K}^{-1}$. On the other hand, the basement rocks of Paleoproterozoic and Archean ages appear to be characterized by slightly higher values, in the range of 2.9 to $4.3 \mathrm{Wm}^{-1} \mathrm{~K}^{-1}$. The sedimentary rock formations of Mesozoic and Tertiary periods are found to have relatively low thermal conductivity, in the range of 2.2 to $3.2 \mathrm{~W} \mathrm{~m}^{-1} \mathrm{~K}^{-1}$.

The data in Table 4 may also be used for examining the largescale inter-formational variations in thermal conductivity. For example, the map of Figure 8 illustrates the regional distribution of mean thermal conductivity values of the main geologic formations. It reveals a pattern similar to that depicted in geologic maps of the study area, a consequence of the implicit assumption that thermal conductivity is constant within any specific geologic formation. The weakness of this approach is that it amounts to a strong averaging procedure and ignores eventual intra-formational variations in thermal conductivity.

A better approach in evaluation of regional variations in thermal conductivity is to relate the available experimental data to the lithologic sequences encountered in the wells and petrologic descriptions of outcrops. This allows representative values of thermal conductivity to be assigned to the main rock types. Such representative values and their associated uncertainties are listed in Table 5. As can easily be verified, the metamorphic rocks of the basement complex in the northern parts are characterized by thermal conductivity values in the range of 2.8 to $4.3 \mathrm{Wm}^{-1} \mathrm{~K}^{-1}$. This range is slightly higher than that encountered for rocks of the coastal complex in the south. As expected, the acidic rocks (granites, granitoids and migmatite sequences) have thermal conductivities higher than those of the basic rocks (gabbro and basalt). On the other hand relatively low values, in the range of 1 to $2 \mathrm{Wm}^{-1} \mathrm{~K}^{-1}$, were encountered for unconsolidated sediments and soil samples.

The data in Table 5 also allow evaluation of large-scale regional variations in thermal conductivity. Thus the map of Figure 9 illustrates the regional distribution of mean thermal conductivity values of the main lithologic units in the study area. Note that the thermal conductivity is relatively high in the region adjacent to the São Francisco craton, in the northern parts of the study area.

\section{Site Specific Mean Values}

The data presented in Tables 4 and 5 also allow calculation of weighted mean thermal conductivity values for the sites for which geothermal gradients were calculated. Such values of thermal conductivity are important in the calculation of site specific heat flow values. However, the procedure for calculation of the site specific mean thermal conductivity depends on the method used for the determination of geothermal gradients. Thus, for those sites where the conventional (CVL) method was used, a mean value of thermal conductivity was calculated for the relevant depth section. On the other hand, for sites where the CBT method was used for determining temperature gradients, the mean value of thermal conductivity calculated refers to the entire lithologic sequence encountered, from the surface down to the bottom of the well. The site specific values of thermal conductivity calculated in this manner are presented in Table 6.

Note that the overall mean thermal conductivity for the 32 sites, where thermal gradients were determined using the CVL method, is $3.0 \mathrm{Wm}^{-1} \mathrm{~K}^{-1}$. On the other hand for the $22 \mathrm{si}-$ tes, for which thermal gradients were calculated using the CBT method, the overall mean value of thermal conductivity is only 2.6 $\mathrm{Wm}^{-1} \mathrm{~K}^{-1}$. The relatively low value for the CBT sites is due to the inclusion of low thermal conductivities of partially consolidated materials in near surface layers.

\section{DETERMINATION OF HEAT FLOW VALUES}

All heat flow values reported in the present work are based on the assumption that the thermal regime of the study area is in steady state. In tectonically stable areas of the continental crust transient changes in the thermal regime take place on time scales that are too large for human experiments. Thus the assumption of steady state is quite reasonable.

\section{Methods used in determination of Heat Flow}

In the present work four different methods were employed in determining heat flow, depending on the nature of temperature gradient and thermal conductivity data. The terminology adopted here follows that used for the case of temperature gradients. Thus the designations conventional (CVL), conventional bottom temperature (CBT), aquifer temperature (AQT) and geochemical (GCL) are also retained for the methods of determining heat flow.

In the conventional method (CVL) heat flow $(q)$ is calculated as product of the least square estimate of gradient $(\Gamma)$ and the 
Table 4 - Mean thermal Conductivity values of the main geological formations in the study area. $\sigma$ is the standard deviation.

\begin{tabular}{|c|c|c|c|}
\hline \multirow{2}{*}{ Age } & \multirow{2}{*}{ Geologic Formation } & \multicolumn{2}{|c|}{ Thermal Conductivity $\left(\mathrm{Wm}^{-1} \mathrm{~K}^{-1}\right)$} \\
\cline { 3 - 4 } & & Mean & $\sigma$ \\
\hline Cenozoic & Barreiras & 2.7 & 0.8 \\
\hline & Resende & 2.7 & 0.8 \\
\hline & Emboré & 3.0 & 0.8 \\
\hline Neoproterozoic & Italva & 2.7 & 1.3 \\
\hline & Palmital & 2.7 & 1.3 \\
\hline & Serra dos Órgãos & 3.0 & 1.2 \\
\hline & Sintectonic & 2.9 & 1.0 \\
\hline Paleoproterozoic & C. S. Fidelis & 4.3 & 2.4 \\
\hline & Rio Negro & 3.1 & 1.3 \\
\hline & Paraíba do Sul & 3.1 & 1.3 \\
\hline & Tinguí & 2.9 & 1.6 \\
\hline Archean & Região de Lagos & 2.9 & 1.6 \\
\hline & Juiz de Fora & 3.0 & 2.0 \\
\hline
\end{tabular}

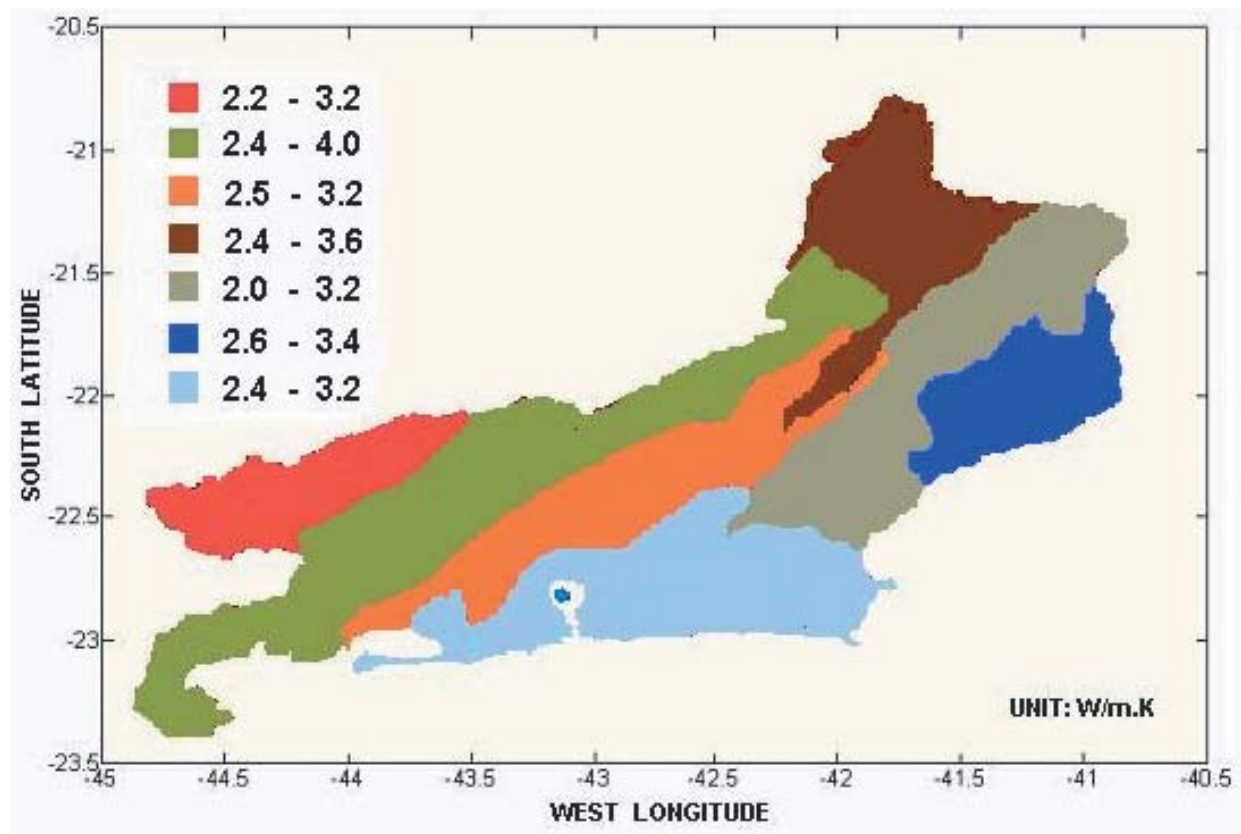

Figure 8 - Thermal conductivity structure of the main geologic formations in the state of Rio de Janeiro. The inset refers to thermal conductivity values in units of $\mathrm{Wm}^{-1} \mathrm{~K}^{-1}$

harmonic mean of thermal conductivity $\left(\lambda_{m}\right)$ :

$$
q=\Gamma \lambda_{m} \pm \sigma_{q}
$$

The error estimate in heat flow, $\sigma_{q}$, is given by the relation for error propagation:

$$
\sigma_{q}=\sqrt{\Gamma^{2} \sigma_{\lambda}^{2}+\lambda^{2} \sigma_{\Gamma}^{2}}
$$

$\sigma_{\lambda}$ is the standard deviation in the determination of $\lambda$ and $\sigma_{\Gamma}$ is the standard deviation in the determination of temperature gradient. As mentioned in the previous section (see also Table 6) the value of $\lambda_{m}$ was calculated making use of experimental data representative of the lithologic sequence of the relevant depth section. A summary of heat flow values obtained by the conventional 
Table $\mathbf{5}$ - Mean thermal conductivity values of the main rock types. $\sigma$ is the standard deviation.

\begin{tabular}{|c|c|c|c|c|}
\hline \multirow{2}{*}{ Municipality } & \multirow{2}{*}{ Formation/Complex } & \multirow{2}{*}{ Rock Type } & \multicolumn{2}{|c|}{ Thermal Conductivity (W/(m K)) } \\
\hline & & & Mean & $\sigma$ \\
\hline \multirow[t]{2}{*}{ Angra dos Reis } & Rio Negro & Biotite Gneiss & 2,9 & 1,0 \\
\hline & Rio Negro & Compact ash colored & 2,9 & 0,8 \\
\hline Cambuci & Juiz de Fora & Gneiss & 3,0 & 1,2 \\
\hline Campos & Campos & Silty Sandstone & 2,7 & 0,8 \\
\hline Carapebus & Reg. Lagos & Silty Sandstone & 2,7 & 0,8 \\
\hline Cordeiro & Serra dos Órgãos & Tonalitic Granitoid & 3,1 & 1,3 \\
\hline Duas Barras & Serra dos Órgãos & Tonalitic Granitoid & 3,1 & 1,3 \\
\hline Itaguaí & Serra dos Órgãos & Granitoid & 3,0 & 1,7 \\
\hline Itaocara & Italva & Gneiss & 3,0 & 2,0 \\
\hline Itatiaia & Resende & Silt & 2,7 & 0,8 \\
\hline Laje de Muriaé & Juiz de Fora & Gneiss & 3,0 & 1,2 \\
\hline Maricá & Palmital & Metamorphic & 2,7 & 1,3 \\
\hline Miguel Pereira & Paraíba do Sul & Biotite Gneiss & 3,1 & 1,3 \\
\hline Miracema & Juiz de Fora & Migmatitic Gneiss & 3,0 & 1,2 \\
\hline Niterói & Sintectonic & Undifferentiated Granite & 3,1 & 1,3 \\
\hline Paraíba do Sul & Paraíba do Sul & Biotite Gneiss & 3,1 & 1,3 \\
\hline Porciúncula & Juiz de Fora & Migmatitic Gneiss & 3,0 & 1,2 \\
\hline Resende & Resende & Silty Sandstone & 2,2 & 0,8 \\
\hline \multirow[t]{2}{*}{ Rio Bonito } & Unidade Tingui & Metamorphic & 2,7 & 0,8 \\
\hline & São Fidélis & Undifferentiated Granite & 2,7 & 1,5 \\
\hline Rio Claro & Paraíba do Sul & Gneiss & 3,1 & 2,1 \\
\hline Rio de Janeiro & São Fidélis & Undifferentiated Granite & 2,7 & 1,5 \\
\hline Sapucaia & Paraíba do Sul & Gneiss & 3,5 & 2,0 \\
\hline St. A. de Pádua & Juiz de Fora & Migmatitic Gneiss & 3,0 & 2,0 \\
\hline S. Gonçalo & São Fidélis & Undifferentiated Granite & 3,3 & 1,8 \\
\hline S.SebastiãodoAlto & Italva & Biotite Gneiss & 3,5 & 2,0 \\
\hline Saquarema & Palmital & Migmatite & 2,7 & 0,8 \\
\hline Seropédica & Rio Negro & Gneisses and Migmatite & 2,7 & 0,8 \\
\hline Silva Jardim & Região dos Lagos & Fluvial Sediments & 1,5 & 0,8 \\
\hline Teresópolis & Serra dos Órgãos & Tonalitic Granitoid & 3,1 & 1,3 \\
\hline Vassouras & Paraíba do Sul & Mesocratic Gneiss & 3,9 & 1,0 \\
\hline Volta Redonda & Italva & Leucocratic Gneiss & 2,8 & 1,2 \\
\hline
\end{tabular}

method is provided in Table 7, along with estimates of the errors involved. Note that the values are found to fall in the range of 30 to $60 \mathrm{~mW} / \mathrm{m}^{2}$.

In the conventional bottom temperature (CBT) method the heat flow $(q)$ is calculated as product of the CBT gradient $\left(\Gamma_{\mathrm{CBT}}\right)$ and weighted mean thermal conductivity:

$$
q=\left\{\frac{\left(T_{C B T}-T_{0}\right)}{\left(Z_{C B T}-Z_{0}\right)}\right\}\left\{\frac{\left(Z_{C B T}-Z_{0}\right)}{\left(\sum_{i=1}^{N} R_{i} h_{i}\right)}\right\}
$$

where $T_{C B T}$ is the temperature at depth $Z_{C B T}, R$ is the ther- mal resistivity of the layer with thickness $h$ and $n$ the number of layers. Note that the first term on the right hand side of equation (6) represent the CBT gradient while the second term in curly brackets represent the weighted mean thermal conductivity of all the layers within the depth interval $\left(Z_{C B T}-Z_{0}\right)$. Obviously, this procedure requires use of thermal conductivity values of the entire lithologic sequence encountered, from the surface down to the bottom of the well. A summary of the heat flow values obtained by the CBT method is given in part (a) of Table 8. The range of heat flow values is 30 to $70 \mathrm{~mW} / \mathrm{m}^{2}$, in relatively close agreement 


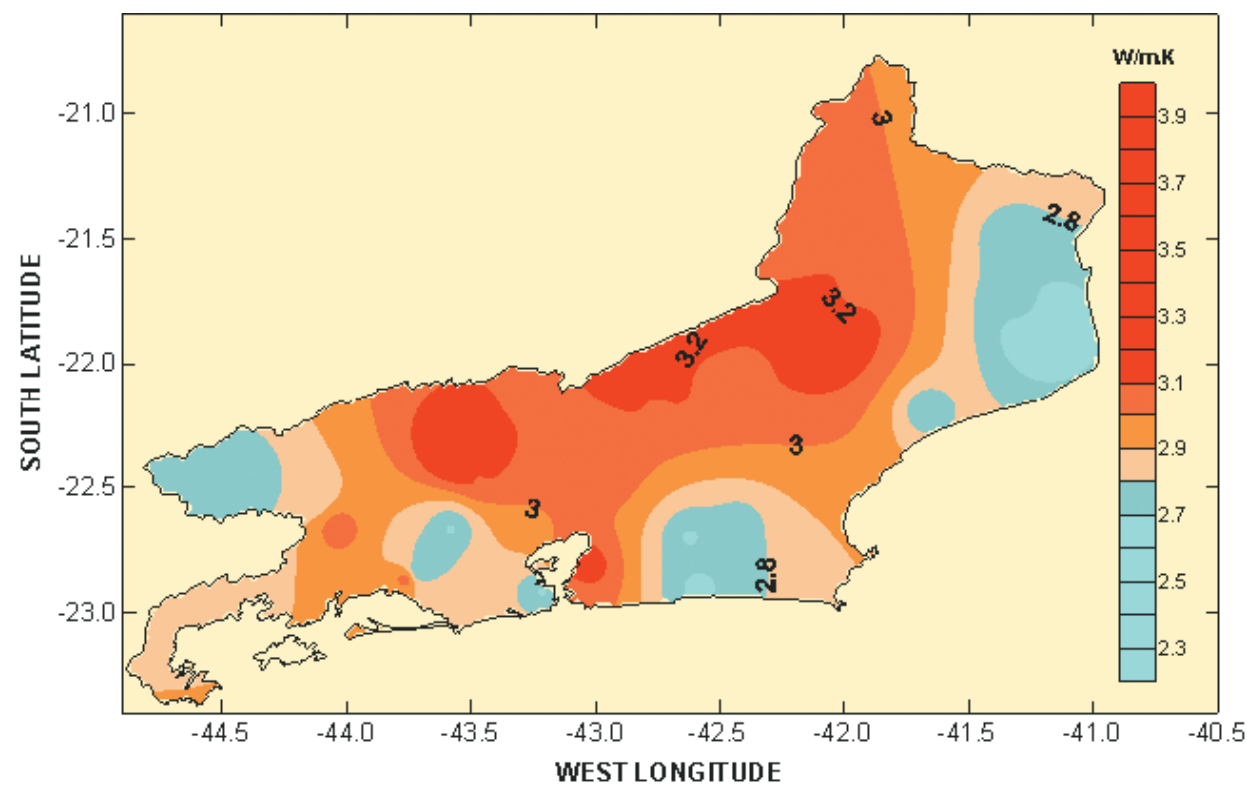

Figure $\mathbf{9}$ - Regional distribution of thermal conductivity values of the main rock types in the state of Rio de Janeiro. The inset refers to contour values are in units of $\mathrm{W} / \mathrm{mK}$.

with those obtained using the conventional method.

In the aquifer temperature (AQT) method the heat flow $(q)$ is calculated using a relation similar to that of equation (6):

$$
q=\left\{\frac{\left(T_{A Q T}-T_{0}\right)}{\left(Z_{A Q T}-Z_{0}\right)}\right\}\left\{\frac{\left(Z_{A Q T}-Z_{0}\right)}{\left(\sum_{i=1}^{N} R_{i} h_{i}\right)}\right\}
$$

where $T_{A Q T}$ is the temperature at depth $Z_{A Q T}, R$ is the thermal resistivity of the layer with thickness $h$ and $n$ the number of layers. Note that the first term on the right hand side of equation (7) represent the AQT gradient while the second term in curly brackets represent the weighted mean thermal conductivity of all the layers within the depth interval $\left(Z_{A Q T}-Z_{0}\right)$. A summary of heat flow obtained by the AQT method is given in part (b) of Table 8 . The values are found to fall in the range of 30 to $70 \mathrm{~mW} / \mathrm{m}^{2}$, in relatively close agreement with those obtained using the conventional method.

In areas of thermal springs heat flow is estimated using the empirical relation:

$$
q=\left(T_{R}-T_{0}\right)\left(\frac{\lambda}{Z_{R}}\right)
$$

where $T_{R}$ is the reservoir temperature at depth $Z_{R}$, estimated using one of the geochemical thermometers and $T_{0}$ the mean annual surface temperature. Note that the inverse of the term $\left(\lambda / Z_{R}\right)$ represents the cumulative thermal resistance of the layer overlying the hydrothermal system. Swanberg \& Morgan (1979) proposed a value of $680^{\circ} \mathrm{Cm}^{2} / \mathrm{W}$ for the thermal resistance term, for areas where silica thermometer is employed for estimating reservoir temperatures. Note that this approach implicitly assumes a depth of circulation of approximately $2 \mathrm{~km}$ for the thermal waters.

A summary of heat flow obtained by the geochemical method (GCL) is provided in Table 9. Note that the values obtained are in the range of 30 to $150 \mathrm{~mW} / \mathrm{m}^{2}$, significantly higher than those obtained by CVL, CBT and AQT methods. It is possible that this is a consequence of the tendency to overestimate temperature gradients in the geochemical method. On the other hand, the possibility that the localities of thermal springs are characterized by higher heat flow at deeper depths cannot entirely be ruled out. Measurements in deep holes using conventional methods are necessary to verify this possibility.

\section{Regional Variations}

The heat flow data presented in Tables 7 to 9 were used in examining the regional distribution of heat flow. As in the case of thermal gradients, two different data sets were considered: one based exclusively on the relatively more reliable CVL, CBT and AQT data and the other one of mixed quality that include also the less reliable GCL estimates.

The regional heat flow map based on the CVL, CBT and AQT data sets is presented in Figure 10. It reveals that the heat flow is low to normal (in the range of 30 to $60 \mathrm{~mW} / \mathrm{m}^{2}$ ) in most part of the 
Table 6 - Mean thermal Conductivity $(\lambda)$ values of the sites where CVL (selected interval) and CBT (whole interval) methods were used in determination of gradients. The values are in units of W/(m.K). $\sigma$ is the standard deviation.

\begin{tabular}{|c|c|c|c|c|c|}
\hline \multirow{2}{*}{ Locality } & \multicolumn{2}{|c|}{$\lambda$ for selected interval } & \multirow{2}{*}{ Locality } & \multicolumn{2}{|c|}{$\lambda$ for whole interval } \\
\hline & Mean & $\sigma$ & & Mean & $\sigma$ \\
\hline Bonfim & 2,9 & 0,58 & Monte Verde & 2,8 & 0,42 \\
\hline Virada Leste & 2,9 & 0,64 & Consel. Josino & 2,3 & 0,35 \\
\hline Baixa Grande & 2,7 & 0,54 & Carapebus & 2,2 & 0,33 \\
\hline Boa Vista & 2,7 & 0,59 & Matadouro & 2,5 & 0,38 \\
\hline São Sebastião & 2,2 & 0,44 & Duas Barras-DBP4 & 3,0 & 0,45 \\
\hline Uenf 2 & 3,0 & 0,60 & Cel. Teixeira & 2,6 & 0,39 \\
\hline Duas Barras-DBP1 & 3,1 & 0,61 & Jaguarembé & 2,6 & 0,39 \\
\hline Duas Barras-DBP2 & 3,1 & 0,67 & Próximo Dutra & 2,2 & 0,33 \\
\hline Duas Barras-DBP3 & 3,1 & 0,64 & Laje do Muriaé & 3,0 & 0,45 \\
\hline Manoel Ribeiro & 2,7 & 0,53 & Maricá-M.RibeiroP1 & 2,5 & 0,38 \\
\hline Miracema & 3,0 & 0,60 & Maricá-M.RibeiroP3 & 2,6 & 0,39 \\
\hline Cruz das Almas & 3,1 & 0,62 & Miguel Pereira & 2,7 & 0,41 \\
\hline Santa Clara & 3,0 & 0,60 & Paraíso Tobias & 3,0 & 0,45 \\
\hline Resende-P2 & 2,7 & 0,54 & Cafubá & 3,0 & 0,48 \\
\hline Resende-D. Maria & 2,7 & 0,59 & Piratininga & 2,7 & 0,41 \\
\hline Passa Três & 3,1 & 0,62 & Ponte Preta & 1,7 & 0,26 \\
\hline Aparecida & 3,5 & 0,70 & Resende-P1 & 2,7 & 0,41 \\
\hline Jamapara-P3 & 3,5 & 0,77 & Boa Esperança & 2,8 & 0,42 \\
\hline Jamapara-P4 & 3,5 & 0,74 & Aparecida & 2,9 & 0,44 \\
\hline Tribobó & 3,1 & 0,62 & Jamapara & 2,9 & 0,44 \\
\hline S.S. do Alto-P1 & 3,5 & 0,70 & Faz. Brasil & 1,4 & 0,21 \\
\hline S.S. do Alto-P2 & 3,5 & 0,77 & Água Quente & 2,4 & 0,36 \\
\hline S.S. do Alto-P3 & 3,5 & 0,74 & - & - & - \\
\hline Gj. S. Antonio & 2,7 & 0,54 & - & - & - \\
\hline Orfanato & 2,7 & 0,57 & - & - & - \\
\hline P.S.Piranema & 2,7 & 0,59 & - & - & - \\
\hline Meudon-BC2 & 3,1 & 0,67 & - & - & - \\
\hline Faz. Texas & 3,1 & 0,61 & - & - & - \\
\hline Meudom & 3,1 & 0,64 & - & - & - \\
\hline Barra do Imbui & 3,1 & 0,61 & - & - & - \\
\hline Massambará & 3,9 & 0,78 & - & - & - \\
\hline Padre Josimo & 2,8 & 0,56 & - & - & - \\
\hline
\end{tabular}

interior of the state of Rio de Janeiro, especially in the northern regions just to the south of São Francisco Craton. Heat flow values lower than $40 \mathrm{~mW} / \mathrm{m}^{2}$ was encountered only in three localities in the municipality of São Sebastião do Alto. The overall pattern of heat flow distribution is similar that observed for the temperature gradients. This is an indication that thermal conductivity variations have only a secondary and subdued effect on regional distribution of heat flow.
Heat flow values higher than $80 \mathrm{~mW} / \mathrm{m}^{2}$ were found in the western parts of the study area, in the region adjacent to the alkaline intrusion of Itatiaia and also in the Resende sedimentary basin. The western and southern boundaries of this heat flow anomaly are not well defined for lack of appropriate data. However, there are some indications that areas with heat flow higher than $80 \mathrm{~mW} / \mathrm{m}^{2}$ extend along the belt of alkaline intrusions between Itatiaia and Cabo Frio. 
Table 7 - Heat flow values calculated using the conventional (CVL) method. $\sigma$ is the standard deviation.

\begin{tabular}{|c|c|c|c|}
\hline \multirow{2}{*}{ Municipality } & \multirow{2}{*}{ Locality } & \multicolumn{2}{|c|}{ Heat Flow $\left(\mathrm{mW} / \mathrm{m}^{2}\right)$} \\
\hline & & Mean & $\sigma$ \\
\hline \multirow[t]{2}{*}{ Angra dos Reis } & Bonfim & 119 & 15.4 \\
\hline & Virada Leste & 67 & 8.6 \\
\hline \multirow{3}{*}{ Campos } & Baixa Grande & 51 & 8.0 \\
\hline & Boa Vista & 70 & 8.5 \\
\hline & UENF2 & 57 & 6.9 \\
\hline \multirow[t]{3}{*}{ Duas Barras } & $\overline{\text { DBP1 }}$ & 46 & 5.5 \\
\hline & DBP2 & 46 & 5.5 \\
\hline & DBP3 & 52 & 10.1 \\
\hline Maricá & M. Ribeiro & 53 & 6.4 \\
\hline Miracema & Centro & 60 & 7.4 \\
\hline Niterói & Cafubá & 43 & 5.2 \\
\hline Paraíba do Sul & C. das Almas & 53 & 6.3 \\
\hline Porciúncula & Santa Clara & 39 & 4.8 \\
\hline \multirow[t]{2}{*}{ Resende } & Centro P2 & 92 & 11.9 \\
\hline & D.Maria & 70 & 10.0 \\
\hline S.Seb.do Alto & V.Barro-P1 & 26 & 3.6 \\
\hline Saquarema & Gj. S. Antonio & 41 & 4.9 \\
\hline \multirow[t]{2}{*}{ Seropédica } & Orfanato & 62 & 7.5 \\
\hline & P.S.Piranema & 59 & 7.1 \\
\hline \multirow[t]{4}{*}{ Teresópolis } & FVM & 64 & 9.5 \\
\hline & Faz. Texas & 67 & 8.1 \\
\hline & $\mathrm{BC2}$ & 49 & 5.9 \\
\hline & Barra Imbui & 64 & 7.7 \\
\hline Vassouras & Massambará & 55 & 6.6 \\
\hline Volta Redonda & Padre Josino & 56 & 6.7 \\
\hline
\end{tabular}

The regional heat flow map based on the complete data set, that includes also estimates by GCL methods, is presented in Figure 11. In this case the zone of high heat flow $\left(>80 \mathrm{~mW} / \mathrm{m}^{2}\right)$ extends over a much larger area in the western parts, a region affected by alkaline magmatism during the Tertiary period. It appears that the heat flow regime of the eastern part of the study area is distinctly different from that of the western part. One of the most likely process responsible for this difference is the residual heat from the Tertiary alkaline magmatic activity. According to Smith and Shaw (1975) residual heat from intrusive magmatism at intracrustal layers may constitute a significant component of near surface conductive heat flux for periods of up to $100 \mathrm{~m}$.y. Recently Hamza et al. (2005a) presented calculations of residual heat from Trindade plume, based on the model of hot spot in a moving medium proposed by Birch (1975). The calculations indicate that for relative velocities of less than one centimeter per year, the trai- ling part of the hot spot trajectory may retain significant amount of residual heat in lower to mid crustal layers.

\section{DISCUSSION AND CONCLUSIONS}

The results obtained in the present work indicate that the geothermal gradients in most parts of the state of Rio de Janeiro fall in the interval of 15 to $30^{\circ} \mathrm{C} / \mathrm{km}$. The mean value is $20.5 \pm 7.2^{\circ} \mathrm{C} / \mathrm{km}$, typical of the gradients commonly encountered in tectonically inactive areas of Precambrian age. Regional distribution as revealed in geothermal maps indicate that the temperature gradients are relatively high $\left(>30^{\circ} \mathrm{C} / \mathrm{km}\right)$ in the western parts compared to the eastern parts of the study area.

Regional distributions of thermal conductivities of the main geological formations and lithologic types are indicative of an approximate trend of decreasing values in the north-south direction. 
Table 8 - Heat flow values by the conventional bottom temperature (CBT) and aquifer temperature (AQT) methods. $\sigma$ is the standard deviation.

(a) - Heat flow values calculated using the CBT method.

\begin{tabular}{|c|c|c|c|}
\hline \multirow{2}{*}{ Municipality } & \multirow{2}{*}{ Locality } & \multicolumn{2}{|c|}{ Heat Flow $\left(\mathrm{mW} / \mathrm{m}^{2}\right)$} \\
\hline & & Mean & $\sigma$ \\
\hline Cambuci & Monte Verde & 70 & 9.0 \\
\hline \multirow[t]{2}{*}{ Campos } & Consel. Josino & 49 & 7.8 \\
\hline & São Sebastião & 55 & 8.7 \\
\hline Carapebus & Centro & 67 & 10.1 \\
\hline Cordeiro & Matadouro & 83 & 12.4 \\
\hline Duas Barras & Centro DBP4 & 48 & 7.2 \\
\hline \multirow[t]{2}{*}{ Itaocara } & Cel. Teixeira & 50 & 7.5 \\
\hline & Jaguarembé & 45 & 9.6 \\
\hline Itatiaia & Próximo Dutra & 36 & 5.5 \\
\hline Laje de Muriaé & Centro & 70 & 10.6 \\
\hline \multirow[t]{2}{*}{ Maricá } & Manoel Rib - P1 & 64 & 9.6 \\
\hline & Manoel Ribeiro & 41 & 6.1 \\
\hline Miguel Pereira & Centro & 44 & 6.7 \\
\hline Miracema & Paraíso Tobias & 61 & 10.5 \\
\hline Niterói & Piratininga & 75 & 12.6 \\
\hline Paraíba do Sul & Ponte Preta & 29 & 4.4 \\
\hline Resende & Centro P1 & 65 & 9.8 \\
\hline Rio Bonito & Boa Esperança & 92 & 13.8 \\
\hline São Gonçalo & Tribobó & 78 & 11.7 \\
\hline \multirow[t]{2}{*}{ São Seb. do Alto } & V.Barro-VBP2 & 24 & 5.9 \\
\hline & V.BarroVBP3 & 21 & 3.2 \\
\hline \multirow[t]{3}{*}{ Sapucaia } & Aparecida & 41 & 6.2 \\
\hline & Jamapara P3 & 41 & 6.2 \\
\hline & Jamapara P4 & 61 & 9.1 \\
\hline
\end{tabular}

(b) - Heat flow values calculated using the AQT method.

\begin{tabular}{|c|c|c|c|}
\hline \multirow{2}{*}{ Municipality } & \multirow{2}{*}{ Locality } & \multicolumn{2}{|c|}{ Heat Flow $\left(\mathrm{mW} / \mathrm{m}^{2}\right)$} \\
\cline { 3 - 4 } & & Mean & $\sigma$ \\
\hline Teresópolis & Água Quente & 111 & 57.9 \\
\hline Campos & São Sebastião & 95 & 29.9 \\
\hline Cordeiro & Cordeiro & 61 & 26.0 \\
\hline
\end{tabular}

The underlying mechanism for the occurrence of such a trend is not entirely clear, in view of the limitations of the data set. On the other hand, the crustal segments of the northern parts are relatively more deeply eroded than the southern counterparts. The deep seated rocks are in general of relatively higher metamorphic grade and density, less porous and more compact. These are also conditions that favor relatively higher thermal conductivity. Hence, the observed trend of decreasing values in the north-south direction is likely to be indicative of a direct correlation between thermal conductivity and metamorphic grade.

The mean value of heat flow by the conventional method is $64 \pm 28 \mathrm{~mW} / \mathrm{m}^{2}$. Most of the individual values are found to fall in the interval of 40 to $80 \mathrm{~mW} / \mathrm{m}^{2}$, a range that may be considered as typical of continental crust. Nevertheless, the regional distribution reveals that heat flow is relatively high $\left(>80 \mathrm{~mW} / \mathrm{m}^{2}\right)$ in the western parts of the study area. Residual heat from the Tertiary alkaline magmatic activity is pointed out as the most likely process responsible for this difference. 
Table $\mathbf{9}$ - Heat flow by the geochemical (GCL) method. The column under the letters GT indicates the type of geochemical thermometer. $\sigma$ is the standard deviation.

\begin{tabular}{|c|c|c|c|c|}
\hline \multirow{2}{*}{ Municipality } & \multirow{2}{*}{ Spring } & \multirow{2}{*}{ Geothermometer } & \multicolumn{2}{|c|}{ Heat Flow $\left(\mathrm{mW} / \mathrm{m}^{2}\right)$} \\
\hline & & & q & $\sigma$ \\
\hline Campos & Pedra Alecrim & $\mathrm{SiO2}$ & 54 & 6.6 \\
\hline Itaguaí & Poço 2 & $\mathrm{SiO2}$ & 88 & 10.6 \\
\hline Niterói & Ingá & $\mathrm{SiO2}$ & 108 & 13.0 \\
\hline \multirow[t]{3}{*}{ Paraíba do Sul } & Salutaris & $\mathrm{SiO} 2$ & 84 & 33.8 \\
\hline & Salutaris & $\mathrm{Na}-\mathrm{K}-\mathrm{Ca}$ & 84 & 33.8 \\
\hline & Salutaris & $\mathrm{Na} / \mathrm{K}$ & 84 & 10.1 \\
\hline \multirow[t]{3}{*}{ Rio Bonito } & Catimbau & $\mathrm{SiO} 2$ & 108 & 12.9 \\
\hline & Catimbau & $\mathrm{Na}-\mathrm{K}-\mathrm{Ca}$ & 108 & 13.1 \\
\hline & Catimbau & $\mathrm{Na} / \mathrm{K}$ & 108 & 23.3 \\
\hline \multirow[t]{6}{*}{ Rio de Janeiro } & Agua Meyer & $\mathrm{Na}-\mathrm{K}-\mathrm{Ca}$ & 100 & 12.0 \\
\hline & Agua Meyer & $\mathrm{Na} / \mathrm{K}$ & 100 & 12.0 \\
\hline & Nazareth & $\mathrm{Na} / \mathrm{K}$ & 120 & 26.9 \\
\hline & Santa Cruz & $\mathrm{SiO2}$ & 78 & 9.4 \\
\hline & Silva Manuel & $\mathrm{Na} / \mathrm{K}$ & 73 & 16.7 \\
\hline & Silva Manuel & $\mathrm{Na}-\mathrm{K}-\mathrm{Ca}$ & 73 & 9.5 \\
\hline \multirow[t]{5}{*}{ S. A. de Pádua } & Iodetada & $\mathrm{SiO2}$ & 78 & 9.4 \\
\hline & Iodetada & $\mathrm{Na}-\mathrm{K}-\mathrm{Ca}$ & 78 & 10.2 \\
\hline & Iodetada & $\mathrm{Na} / \mathrm{K}$ & 78 & 19.8 \\
\hline & Ag. S. Gonçalo & $\mathrm{SiO2}$ & 99 & 11.9 \\
\hline & Ag. S. Gonçalo & $\mathrm{Na}-\mathrm{K}-\mathrm{Ca}$ & 99 & 12.8 \\
\hline
\end{tabular}

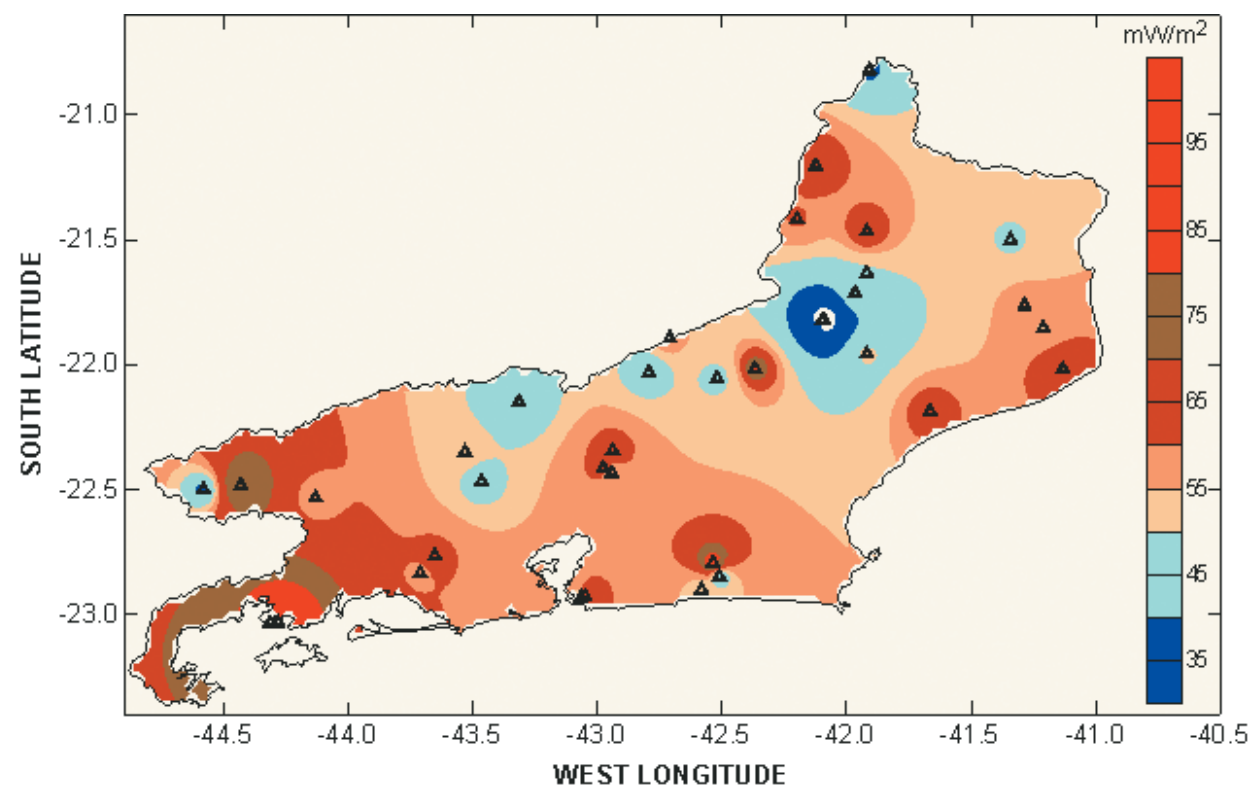

Figure 10 - Regional heat flow map based on the selected data sets: conventional (CVL), conventional bottom temperature (CBT) and aquifer temperature (AQT). 


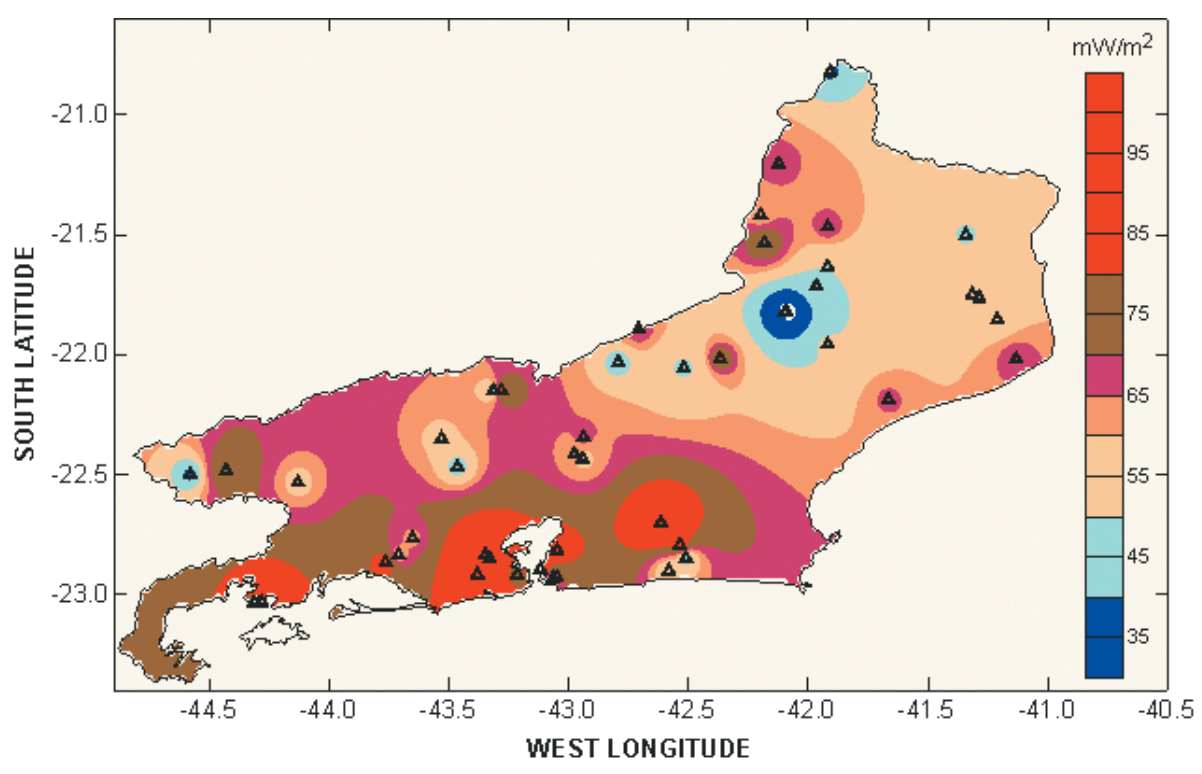

Figure 11 - Regional heat flow map based on the complete data set that includes also estimates by the GCL method.

At present heat flow data are available for 72 localities which mean that the overall data density for the state of Rio de Janeiro is one per 600 square kilometers area. This may appear as too low but it is useful to note that it is more than an order of magnitude higher than the global heat flow data density. According to current statistics Rio de Janeiro stands out as the state with the highest data density for geothermal measurements in Brazil. Nevertheless, the limit of spatial resolution in heat flow maps is no better than several tens of kilometers. This may be considered satisfactory for regional heat flow investigations, but is still too low if comparative studies are to be undertaken against other ground based gravity and magnetic data.

Finally, it is convenient to keep in mind the main limitations of the database. The current geographic distribution of geothermal database is somewhat non-homogeneous, there being several areas in the eastern and western parts of the State for which relevant data are not available. Most of the data has been acquired in bore holes and wells with depths less than a few hundred meters. Lack of availability of deep drill holes has not allowed direct measurements at depths reaching into the mid sections of the upper crust. Thus the conclusions of this work should be viewed in proper perspective, subject to confirmation by measurements in deeper drill holes.

\section{ACKNOWLEDGEMENTS}

The geothermal project of the State of Rio de Janeiro, which served as the background for heat flow measurements, received support from Fundação Amparo à Pesquisa do Estado do Rio de Janeiro - FAPERJ (Process n E-26/151. 920/2000). A large part of the samples used for thermal conductivity measurements were obtained from the Geology Department of the State University of Rio de Janeiro - UERJ. The first author of this paper has been a recipient of a scholarship granted by Coordenadoria de Aperfeiçoamento de Pesquisa e Ensino Superior - CAPES, during the period $2001-2003$.

\section{REFERENCES}

ALMEIDA FFM. 1967. Origem e evolução da Plataforma Brasileira, Boletim DGM/DNPM, Rio de Janeiro, Brasil.

ALMEIDA FFM. 1977. 0 Cráton do São Francisco, Revista Brasileira de Geociências, São Paulo, 23(7): 349-364.

ALMEIDA FFM. 1991. 0 alinhamento magmático de Cabo Frio, ॥ Simpósio de Geologia do Sudeste, São Paulo, Atas, p. 423-428.

ALMEIDA FFM, HASUI Y \& CARNEIRO CDR. 1975. 0 lineamento de Além Paraíba, Anais da Academia Bras. Ciênc. Res. Comum. 47(3/4): 575.

ARAÚJO RLC. 1978. Pesquisas de fluxo térmico na chaminé alcalina de Poços de Caldas, Tese de Mestrado, Universidade de São Paulo, São Paulo, Brasil.

BEVINGTON PR. 1969. Data reduction and error analysis for the physical sciences, McGraw-Hill, New York.

BIRCH F. 1975. Conductive heat flow anomalies over a hot spot in a moving medium, J. Geophys. Res., 80(35): 4825-4827. 
BOLDITZAR T. 1958. The distribution of temperature in flowing wells. Am. J. Sci., 256: 294-298.

BULLARD EC. 1954. The flow of heat through the floor of the Atlantic Ocean. Proc. R. Soc. London A, 222: 408-429.

BULLARD EC. 1965. Historical introduction to terrestrial heat flow, in: LEE WHK (Ed.), Terrestrial Heat Flow, Geophys. Mon. No. 8, 1-6, American Geophysics Union, Washington.

CARSLAW HS \& JAEGER JC. 1959. Conduction of heat in solids, Clarendon Press, Oxford.

CENTRO DE INFORMAÇÕES E DADOS DO RIO DE JANEIRO FUNDAÇÃO CIDE. 2002. Mapa Geológico do Estado do Rio de Janeiro. Disponível em: <http://www.cide.rj.gov.br/download/territorio/territorios.asp > Acesso em: jun. 2002

CERRONE BN \& HAMZA VM. 2003. Variações paleoclimáticas no Estado do Rio de Janeiro com base no método geotérmico, $8^{\circ}$ International Congress of the Brazilian Geophysical Society, Rio de Janeiro.

FONSECA MJG. 1998. Mapa Geológico do Estado do Rio de Janeiro, Escala 1:400.000, Publicação Departamento Nacional da Produção Mineral (DNPM), Brasília (DF).

FOURNIER RO. 1981. Application of water geochemistry to geothermal exploration and reservoir engineering, In Geothermal Systems: Principles and Case Histories, RYBACH L \& MUFFLER LJP. (Eds.), Wiley, New York, 109-143.

FREITAS RO. 1944. Jazimento de rochas alcalinas no Brasil Meridional Min. Met., 8(43): 45-48.

GIGGENBACH WF. 1988. Geothermal solute equilibria. Derivation of NaK-Mg-Ca geoindicators. Geochim. Cosmochim. Acta, 52: 2749-2765.

GOMES AJL. 2004. Avaliação de Recursos Geotermais do Estado do Rio de Janeiro, Tese de Mestrado, Publicação Especial nº 02/2004, Observatório Nacional, Rio de Janeiro (Brazil).

GOMES AJL \& HAMZA VM. 2003. Avaliação de Recursos Geotermais do Estado do Rio de Janeiro, $8^{\circ}$ International Congress of the Brazilian Geophysical Society, Rio de Janeiro.

GOMES AJL \& HAMZA VM. 2004. Mapeamento de Gradiente Geotérmico no Estado de São Paulo, $1^{\circ}$ Simpósio Regional da SBGf, São Paulo.

HAMZA VM. 1991. Evidências Geotérmicas sobre Variações Climáticas recentes no Hemisfério Sul, $2^{\circ}$ International Congress of the SBGf, Vol. II, 971-976, Salvador.

HAMZA VM. 1997. Were there moving 'plumelets' in the South Brazilian continental lithosphere? $5^{\circ}$ International Congress of the Brazilian Geophysical Society, 911-913.

HAMZA VM. 1998. A proposal for continuous recording of subsurface temperatures at the sites of geomagnetic field observatories, Rev. Geofisica Instituto Panamericano de Geografia e Historia, 48: 183-198.
HAMZA VM, CHI CM \& MARANGONI YR. 1980. 0 método de fonte linear para medidas de Condutividade Térmica em meios porosos, $8^{\circ}$ Encontro sobre escoamento em meios porosos, Dep. de Física, UFPR, Paraná.

HAMZA VM \& ESTON SM. 1981. Assessment of Geothermal resources of Brazil, Zbl. Geol. Palaontol., Stuttgart, 1: 128-155.

HAMZA VM, CARDOSO RA \& GOMES AJL. 2005a. Gradiente e fluxo geotérmico na região sudeste: indícios de calor residual do magmatismo alcalino e implicações para maturação térmica de sedimentos na plataforma continental, Anais do III Simpósio de Vulcanismo e Ambientes Associados, Cabo Frio, Rio de Janeiro, 319-324.

HAMZA VM \& MUÑOZ M. 1996. Heat Flow map of South America, Geothermics, 25(6): 599-646.

HAMZA VM, SILVA DIAS FJS, GOMES AJL \& TERCEROS ZD. 2005b. Numerical and functional representation of regional heat flow in South America, Phys. Earth Planet. Interiors, 152: 223-256.

HARALYI NLE \& HASUI Y. 1982. The gravimetric information and the Archean - Proterozoic structural framework of Eastern Brazil. Rev Bras Geocienc., 12: 160-166.

HERZ N. 1977. Timing of spreading in the South Atlantic: Information from Brazilian Alkalic rocks, Geol. Soc. Am. Bull., 88: 101-112, Washington (USA).

HURTER SJ. 1987. Aplicação de geotermômetros químicos em águas de fontes brasileiras na determinação do fluxo geotérmico. Unpublished M.Sc. Thesis, University of São Paulo.

HURTER SJ, ESTON SM \& HAMZA VM. 1983. Coleção Brasileira de Dados Geotérmicos Série 2 - Fontes Termais. Publication No. 1233. Instituto de Pesquisas Tecnológicas do Estado de São Paulo s/a - IPT, $111 \mathrm{pp}$.

KLEIN VC \& VIEIRA AC. 1980. Vulcões do Rio de Janeiro - breve geologia e perspectivas. Min. Met. Rio de Janeiro, 44(419): 44-46.

LACHENBRUCH AH \& BREWER N. 1959. Dissipation of the temperature effect of drilling a well in Arctic Alaska, Bulletin, 1083-C. U.S. 1705, Geological Survey, Washington, USA, pp. 73-109.

MARANGONI YR. 1986. Estudo comparativo entre métodos de medidas de condutividade térmica de materiais geológicos. Unpublished M.Sc. Thesis, University of São Paulo.

MINISTÉRIO DA AGRICULTURA. 1969. Normais Climatológicas (Minas Gerais - Espírito Santo - Rio de Janeiro - Guanabara), v. 3, Rio de Janeiro.

MONGELLI F. 1968. Um método per la determinazione in laboratório della conducibilitá termica dlle rocce, Boll. Geof. Teor. Appl., X, 51-58.

OLIVEIRA JAD, MACHADO FILHO L, RIBEIRO MW, LIU CC \& MENESES PR. 1977. Geologic Map of the State of Rio de Janeiro (in Portuguese), Scale 1:400.000. Departamento de Recursos Minerais, Rio de Janeiro. 
RIBEIRO FB. 1987. Estimation of formation Temperature and Heat Flow from measurements made in shallow water wells, Revista Brasileira de Geofísica, 5(2): 117-126.

RICCOMINI C, ALMEIDA FFM DE \& COIMBRA AM. 1983. Sobre a ocorrência de um derrame de ankaramito na bacia de Volta Redonda, Simp. Reg. Geol., São Paulo, Bol. Res., 4: 23-24.

RO0TS WK. 1969. Fundamentals of temperature control, Academic Press, New York, $221 \mathrm{pp}$

SANTOS J, HAMZA VM \& SHEN PY. 1986. A method for measurements of terrestrial heat flow density in water wells, Revista Brasileira de Geofísica, 4(2): 45-53.

SHEN PY \& BECK AE. 1991. Least squares inversion of borehole tem- perature measurements in functional space, J. Geophys. Res., 96(B12): 19965-19979.

SMITH RL \& SHAW HR. 1975. Igneous-related geothermal systems. In: WHITE DE \& WILLIAMS DL (Eds.), Assessment of Geothermal Resources of the United States - 1975, U. S. Geol. Surv. Circ. 726: 58-83.

SWANBERG CA \& MORGAN P. 1979. The linear relation between temperature based on silica content of groundwater and regional heat flow: a new heat flow map of the United States, Pure Appl. Geophys., 117: 227-241.

VERMA SP \& SANTOYO E. 1995. New improved equations for $\mathrm{Na} / \mathrm{K}$ and $\mathrm{SiO}_{2}$ geothermometers by error propagation, World Geothermal Congress, Florence, Italy, pp. 963-968.

\section{NOTES ABOUT THE AUTHORS}

Antonio Jorge de Lima Gomes. Born in Viseu (Portugal) on November 25, 1955. Graduated in Civil Engineering in 1981 and concluded Specialization in Environmental Sciences at the State University of Rio de Janeiro. Has formally recognized status for teaching undergraduate courses in Physics, Mathematics and Applied Geophysics. Professional experience includes administrative positions in oil refinery, tire and rubber company and engineering firms. Obtained his Masters Degree in Geophysics in 2003 and is currently enrolled in Ph.D. program at the National Observatory in Rio de Janeiro.

Valiya Mannathal Hamza. Born in India on 15th June, 1941. Obtained his Graduate degree in Physics in 1962 and Masters Degree in Applied Physics in 1964, at the University of Kerala (India). Concluded Ph.D. degree in Geophysics in 1973 at the University of Western Ontario (Canada). He has been Associate Professor of the University of São Paulo, during 1974 to 1981, and Research Supervisor at the Institute of Technology Research - IPT, during 1982 to 1993 . Has held positions as Secretary of the International Heat Flow Commission - IHFC and member of the Executive Committee of the International Association of Seismology and Physics of the Earth's Interior - IASPEl. He is currently Full Professor at the National Observatory (ON/MCT) in Rio de Janeiro. 